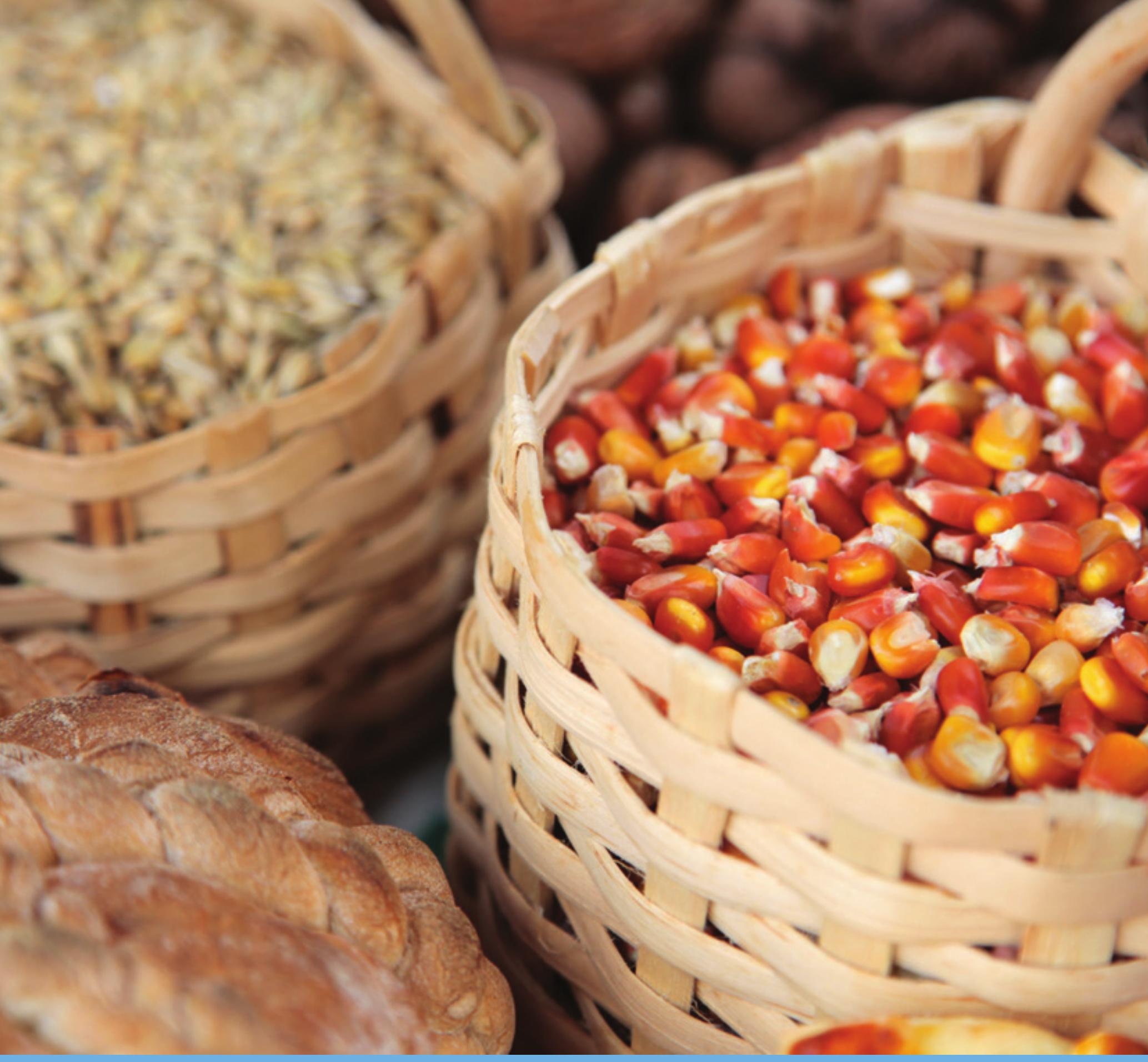

Proficiency test for deoxynivalenol (DON), acetyl-DONs and DON-3G in cereals

EURL-PT-MP01 (2018)

D.P.K.H. Pereboom, R.C.J. van Dam, T.C. de Rijk, M. de Nijs, J.G.J. Mol

n. win

WAGENINGEN

UNIVERSITY \& RESEARCH 



\section{Proficiency test for deoxynivalenol (DON), acetyl-DONs and DON-3G in cereals}

EURL-PT-MP01 (2018)

D.P.K.H. Pereboom, R.C.J. van Dam, T.C. de Rijk, M. de Nijs, J.G.J. Mol 
D.P.K.H. Pereboom, R.C.J. van Dam, T.C. de Rijk, M. de Nijs, J.G.J. Mol, 2019. Proficiency test for deoxynivalenol (DON), acetyl-DONs and DON-3G in cereals; EURL-PT-MPO1 (2018). Wageningen, RIKILT Wageningen University \& Research, RIKILT report 2019.007. 46 pp.; 0 fig.; 4 tab.; 15 ref.

Project number: WOT-02-001-064 1287362201-EURLMP

Project title: EURL mycotoxins \& plant toxins 2018 (EURLMP 1.3.1 PT MYCO)

Coordinator proficiency tests: D.P.K.H. Pereboom

Project leader: M. de Nijs

Scientists: R.C.J. van Dam, T.C. de Rijk, J.G.J. Mol

This report can be downloaded for free at https://doi.org/10.18174/476812 or at www.wur.eu/rikilt (under RIKILT publications).

(C) 2019 RIKILT Wageningen University \& Research, institute within the legal entity Wageningen Research Foundation. Hereinafter referred to as RIKILT.

The client is allowed to publish or distribute the full report to third parties. Without prior written permission from RIKILT it is not allowed to:

a) publish parts of this report;

b) use this report or title of this report in conducting legal procedures, for advertising, acquisition or other commercial purposes;

c) use the name of RIKILT other than as the author of this report.

P.O. Box 230, 6700 AA Wageningen, The Netherlands, T +31(0)317 4802 56, E info.RIKILT@wur.nl, www.wur.eu/rikilt. RIKILT is part of Wageningen University \& Research.

This report from RIKILT has been produced with the utmost care. However, RIKILT does not accept liability for any claims based on the contents of this report.

RIKILT report 2019.007

Distribution list:

- Participating laboratories

- Frans Verstraete, Directorate-General for Health \& Food Safety 


\section{Contents}

$\begin{array}{ll}\text { Summary } & 5\end{array}$

1

$\begin{array}{ll}\text { Introduction } & \mathbf{7}\end{array}$

2

$\begin{array}{ll}\text { PT Material } & 8\end{array}$

2.1 Scope of the PT $\quad 8$

2.2 Material preparation $\quad 8$

$\begin{array}{lll}2.3 & \text { Sample identification } & 8\end{array}$

$\begin{array}{lll}2.4 & \text { Homogeneity study } & 8\end{array}$

2.5 Stability of the materials 9

$3 \quad$ Organisational details $r$

$\begin{array}{lll}3.1 & \text { Participants } & 10\end{array}$

3.2 Material distribution and instructions 10

$\begin{array}{ll}\text { Evaluation of results } & 11\end{array}$

4.1 Calculation of the assigned value $\quad 11$

4.2 Standard deviation for proficiency assessment $\left(\sigma_{\mathrm{P}}\right) \quad 11$

4.3 Quantitative performance (z-scores) 11

$\begin{array}{lll}4.4 & \text { Evaluation of non-quantified results } & 12\end{array}$

4.5 False positives and false negatives 12

$5 \quad$ Assessment of participants' performance $\quad 13$

$\begin{array}{lll}5.1 & \text { Scope and LOQ } & 13\end{array}$

$\begin{array}{lll}5.2 & \text { Analysis methods } & 13\end{array}$

$\begin{array}{lll}5.3 & \text { Performance } & 14\end{array}$

$\begin{array}{lll}5.4 & \text { Robust relative standard deviation } & 14\end{array}$

6 Conclusions $r$

$\begin{array}{ll}\text { References } & 16\end{array}$

$\begin{array}{lll}\text { Annex } 1 \quad \text { List of participants } & 17\end{array}$

$\begin{array}{lll}\text { Annex } 2 & \text { Codification of the samples } & 18\end{array}$

Annex 3 Statistical evaluation of homogeneity data 19

$\begin{array}{lll}\text { Annex } 4 & \text { Statistical evaluation of stability data } & 23\end{array}$

$\begin{array}{lll}\text { Annex } 5 & \text { Invitation letter } & 26\end{array}$

$\begin{array}{lll}\text { Annex } 6 & \text { Instruction letter } & 29\end{array}$

$\begin{array}{lll}\text { Annex } 7 & \text { Scope and LOQ } & 30\end{array}$

$\begin{array}{lll}\text { Annex } 8 & \text { Method details } & 31\end{array}$

Annex $9 \quad$ Results material A (wheat) 33

$\begin{array}{lll}\text { Annex } 10 & \text { Results material B } & 39\end{array}$

$\begin{array}{lll}\text { Annex } 11 & \text { Overview performance per laboratory } & 45\end{array}$ 



\section{Summary}

A proficiency test (PT) for quantitative of deoxynivalenol (DON), 3-acetyl-DON (3-Ac-DON), 15-acetyl-deoxynivalenol (15-Ac-DON), and deoxynivalenol-3-glucoside (DON-3G) in wheat and maize was organised by the European Union Reference Laboratory for mycotoxins \& plant toxins between March-June 2018. DON is a regulated mycotoxin in the EU. Acetyl-DONs and DON-3G were included in this PT because data collection and monitoring is recommended by EFSA, and insight in analytical performance is needed also for these substances. The primary goal was to assess the proficiency of National Reference Laboratories (NRLS).

In total 50 participants from 29 countries registered (Annex 1). This included NRLs from all EU member states, and a number of official laboratories.

Two food/feed materials, wheat (A) and maize (B), were prepared containing DON, 3-Ac-DON, 15-Ac-DON, and DON-3G. The starting materials were naturally contaminated with low levels of DON, and in case of maize also with 15-acetyl-DON and DON-3G. Levels were artificially increased by spiking with DON, 3-Ac-DON and 15-Ac-DON, and wheat also with DON-3G. Both materials were sufficiently homogeneous and stable during the course of the PT. Each participant received one test sample per material.

The assigned values were derived from the consensus of the results submitted by the participants and ranged from 35 to $750 \mu \mathrm{g} / \mathrm{kg}$ for the different mycotoxins. The proficiency of the participants was assessed through z-scores, calculated using the assigned value and a relative target standard deviation of $25 \%$.

All participants submitted results for DON and satisfactory z-scores were obtained by all participants exept 2. Acetyl-DONs and DON-3G were covered by less than half and less than one third of the laboratories, respectively. The laboratories that did have these mycotoxins in their scope had adequate performance in most cases $(\geq 79 \%)$. In this PT, four false positives and two false negatives were reported, all related to 15 -acetyl-DON. In some cases, the limits of quantification (LOQ) were high in relation to typical occurrence data.

Approximately two third of the laboratories used methods based on LC-MS/MS. The others mainly used methods based on LC-UV involving an IAC clean-up. The interlaboratory reproducibility $\left(R_{S D_{R}}\right)$ ranged from $14 \%$ to $28 \%$ without clear dependency regarding the mycotoxin or concentration.

Characteristics of the PT materials and the outcome of this PT are summarised in Table 1. 
Table 1 Summary of proficiency test parameters and participants' performance.

\begin{tabular}{|c|c|c|c|c|c|c|c|c|c|}
\hline \multirow[b]{2}{*}{ Mycotoxin } & \multirow[b]{2}{*}{ Matrix } & \multirow{2}{*}{$\begin{array}{l}\text { Assigned } \\
\text { value } \\
(\mu g / k g)\end{array}$} & \multirow{2}{*}{$\begin{array}{l}\text { Uncert. } \\
\text { ( } \mu g / k g)\end{array}$} & \multirow{2}{*}{$\begin{array}{c}\text { Robust } \\
\text { RSD }^{1 \text { 1) }} \\
\%\end{array}$} & \multicolumn{2}{|c|}{$\begin{array}{c}\text { Included in scope } \\
\text { of labs }\end{array}$} & \multicolumn{3}{|c|}{ No of labs reporting: } \\
\hline & & & & & No & $\%$ & quant value & $<$ LOQ & FN \\
\hline DON & B & 753 & 21.5 & $16 \%$ & 50 & $100 \%$ & 50 & 0 & 0 \\
\hline 3-AC-DON & A & 34.5 & 2.16 & $21 \%$ & 22 & $44 \%$ & 19 & 3 & 0 \\
\hline \multirow[t]{2}{*}{ 15-AC-DON } & A & $<20$ & - & - & \multirow{2}{*}{22} & \multirow{2}{*}{$44 \%$} & $9^{2)}$ & 13 & 0 \\
\hline & B & 154 & 11.6 & $26 \%$ & & & 20 & 2 & 2 \\
\hline \multirow[t]{2}{*}{ DON-3G } & A & 209 & 19.0 & $28 \%$ & \multirow{2}{*}{16} & \multirow{2}{*}{$32 \%$} & 16 & 0 & 0 \\
\hline & B & 35.1 & 1.91 & $14 \%$ & & & 11 & 5 & 0 \\
\hline
\end{tabular}

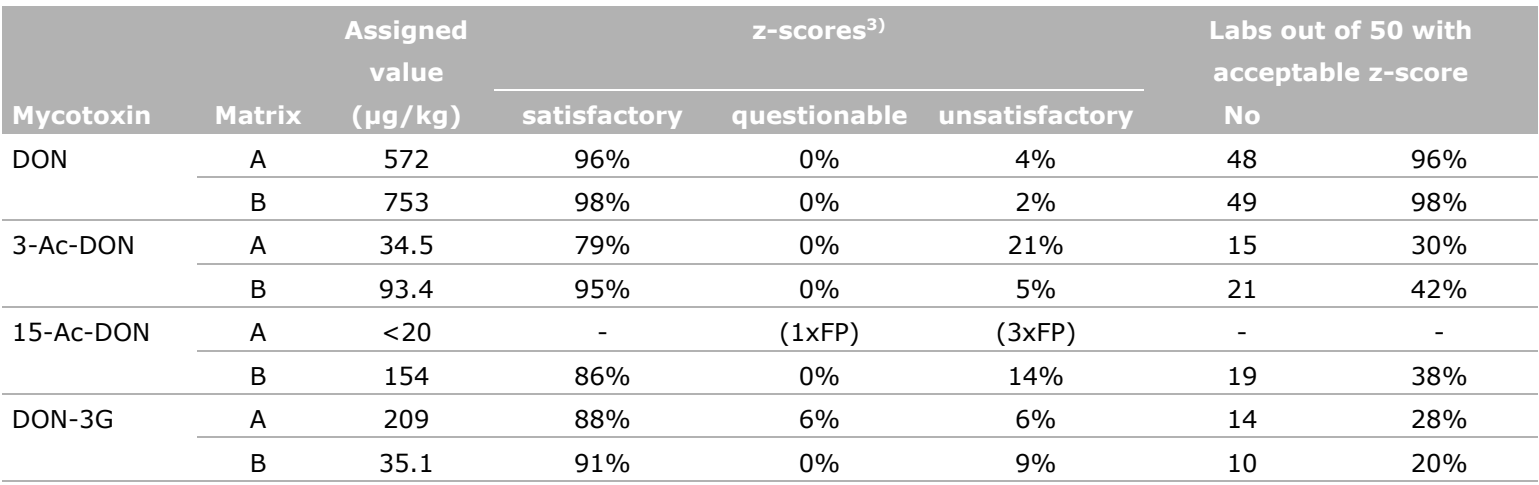

Matrix: $A=$ Wheat, $B=$ Maize

1) robust relative standard deviation (interlaboratory RSD based on participants' results)

2) of which four results were false positives

3) calculated using a fit-for-purpose target RSD for proficiency of $25 \%$. False negatives were counted here as unsatisfactory $z$-score.

4) the number and percentage here means: mycotoxin determined, at sufficiently low LOQ to be quantified, and obtaining a satisfactory z-score. 


\section{Introduction}

Deoxynivalenol (DON) is a secondary fungal metabolite produced by Fusarium species growing on the cereals in the field, especially at temperate climates. It is one of the most frequently occurring mycotoxins in food and feed. Mainly cereals and cereal-based products like pasta, bread and beer are affected. Chemically, DON is classified as type-B trichothecene. In addition to DON, the structurally related acetylated DON and modified forms of DON (e.g. plant-conjugates) have been found in the same type of matrices, of which 3-acetyl-DON (3-Ac-DON), 15-acetyl-DON (15-Ac-DON), and DON-3-glucoside (DON-3G) are the most relevant ones. In a scientific opinion by EFSA [1], the relative concentrations of 3-Ac-DON, 15-Ac-DON and DON-3G to DON were estimated as $10 \%, 15 \%$ and $20 \%$, respectively. In the EFSA opinion, a group-TDI of $1 \mu \mathrm{g} / \mathrm{kg} \mathrm{bw}$ per day for the sum of the four DON forms has been set, and a group-ARfD of $8 \mu \mathrm{g} / \mathrm{kg}$ bw per eating occasion. In current EU legislation maximum levels have been set for DON in food [2] ranging from 200 to $1750 \mu \mathrm{g} / \mathrm{kg}$. In feed guidance values have been set at 0.9 to $12 \mathrm{mg} / \mathrm{kg}$ [3]. Although the acetyl-DONs and DON-3G are not yet included in legislation, their monitoring is recommended $[1,4]$ and therefore the DON-derivatives were included in this proficiency test.

Proficiency testing is conducted to provide participants with a powerful tool to evaluate and demonstrate the reliability of the data that are produced by the laboratory. Proficiency testing is an important requirement of the EU Additional Measures Directive 93/99/EEC [5] and is demanded by ISO/IEC 17025:2017 [6]. Organisation of proficiency tests (PT) is one of the tasks of European Union Reference Laboratories (EURLs) [7]. Here the primary goal is to assess the proficiency of the National Reference Laboratories (NRLs). To facilitate NRLs in their task, official laboratories (OLs) can also participate, in consultation with their NRL. 


\section{PT Material}

\section{$2.1 \quad$ Scope of the PT}

This proficiency test focused on the mycotoxins DON, 3-Ac-DON, 15-Ac-DON and DON-3G in food and feed, using wheat and maize as representative matrices. The target concentrations aimed for (see Table 2) took regulatory limits and commonly found concentrations into account. Levels for the acetyl-DONs and DON-3G included enhanced levels because this was the first time these derivatives were included in an EURL-PT for mycotoxins. The proficiency test was carried out according to ISO/IEC 17043:2010 [8]. At the time of conduct not all of these analyte/matrix combinations were yet part of the accreditation scope, this was achieved in July 2018.

Table 2 Target concentrations $\mu \mathrm{g} / \mathrm{kg}$ of mycotoxins in the PT materials.

\begin{tabular}{|c|c|c|c|c|}
\hline \multirow[t]{2}{*}{ Material } & \multicolumn{4}{|c|}{ Target concentrations ( $\mu \mathrm{g} / \mathrm{kg})$} \\
\hline & DON & 3-Ac-DON & 15-AC-DON & DON-3G \\
\hline A & 400 & 100 & 100 & 200 \\
\hline
\end{tabular}

\subsection{Material preparation}

For preparation of the two PT materials A and B, wheat flour and maize flour were used. The starting materials were naturally contaminated with low levels of DON, and in case of maize also 15-acetyl-DON and DON-3G. Levels were artificially increased by spiking with DON, 3-Ac-DON and 15-Ac-DON, and wheat also with DON-3G. For each material, four kilograms were first fortified by adding a solution of a mycotoxin mix in acetonitrile, aiming at the levels as presented in Table 2. The materials were mixed with approximately six litres of water, homogenized using an industrial mixer according to an in-house standard operating procedure [9]. The fortified slurries were freezedried, homogenized in a Stephan cutter, and stored in the freezer until use.

\subsection{Sample identification}

After homogenization, materials A and B were divided into sub-portions of approximately 35 grams and stored in polypropylene, airtight closed containers of $125 \mathrm{ml}$. After preparation the containers were stored in the freezer until use.

The samples for the participants were randomly selected and coded using a web application designed for proficiency tests. The code used was EURLPT-MP 01/xxx, in which the three-digit number of the code was automatically generated by the web application. One sample set was prepared for each laboratory consisting of one randomly selected sample of each material A and $B$. The codes of the samples for each sample set are presented in Annex 2. For homogeneity and stability testing, randomly selected containers of materials $A$ and $B$ were used.

\subsection{Homogeneity study}

To verify the homogeneity of the PT materials, ten containers of materials $A$ and $B$ were analysed in duplicate for DON, 3-Ac-DON, 15-Ac-DON and DON-3G. The method of analysis is described in detail 
in [10]. In brief, DON and related mycotoxins were extracted from the homogenised sample material after addition of water, by shaking with acidified acetonitrile. After a salt-induced phase partitioning step and centrifugation, an aliquot of the acetonitrile phase was dried with magnesium sulfate. After addition of isotopically labelled internal standards for each of the four mycotoxins, an aliquot of extract was taken, evaporated to dryness, and reconstituted in methanol/water. Analysis was then done by high performance liquid chromatography coupled with tandem mass spectrometry (LC-MS/MS). The homogeneity of the materials was assessed according to the International Harmonized Protocol for Proficiency Testing of Analytical Laboratories [11] and ISO 13528:2015 [12]. The results of the homogeneity study, grand mean with the corresponding $\mathrm{RSD}_{r}$, are presented in Table 3, and the statistical evaluation of materials A and B is presented in Annex 3. Both materials proved to be sufficiently homogeneous for this PT.

Table 3 Concentrations of mycotoxins in material A and B obtained during homogeneity testing.

\begin{tabular}{|c|c|c|c|c|c|c|c|c|}
\hline \multirow{2}{*}{$\begin{array}{c}\text { Material } \\
\text { code }\end{array}$} & \multicolumn{2}{|c|}{ DON } & \multicolumn{2}{|c|}{ 3-Ac-DON } & \multicolumn{2}{|c|}{ 15-AC-DON } & \multicolumn{2}{|c|}{ DON-3G } \\
\hline & $\begin{array}{l}\text { Conc. } \\
(\mu \mathrm{g} / \mathrm{kg}\end{array}$ & $\begin{array}{l}\text { RSDr } \\
(\%)\end{array}$ & $\begin{array}{c}\text { Conc. } \\
(\mu g / k g)\end{array}$ & $\begin{array}{l}\text { RSDr } \\
(\%)\end{array}$ & $\begin{array}{c}\text { Conc. } \\
(\mu \mathrm{g} / \mathrm{kg})\end{array}$ & $\begin{array}{l}\text { RSDr } \\
(\%)\end{array}$ & $\begin{array}{c}\text { Conc. } \\
(\mu \mathrm{g} / \mathrm{kg})\end{array}$ & $\begin{array}{l}\text { RSDr } \\
(\%)\end{array}$ \\
\hline$B$ & 730 & 5.7 & 98.8 & 4.0 & 144 & 8.6 & 24.9 & 8.6 \\
\hline
\end{tabular}

* below lowest validated level, indicative concentration $6 \mu \mathrm{g} / \mathrm{kg}$ with $\mathrm{RSD}_{\mathrm{r}}$ of $27 \%$.

In material $A$ (wheat), the concentrations of the acetyl-DONs were much lower than the anticipated target concentrations. During preparation of this material, the slurry mixing with water at ambient temperature took relatively long and it was hypothesized that acetyl-DON might be (enzymatically) de-acetylated. A follow up experiment in which the wheat and maize starting materials were spiked individually with the acetylated DONs, slurried with water, and left for 4 and 24 hours confirmed conversion of the acetylated DONs into DON in the wheat flour. In maize flour, no 15-Ac-DON and only very minor 3-Ac-DON conversion occurred.

\subsection{Stability of the materials}

The stability of the mycotoxins in the PT materials was assessed according to $[11,12]$. At the day of distribution of the PT samples, six randomly selected containers of each material A and B were stored at $<-70^{\circ} \mathrm{C}$. Under these conditions it is assumed that the mycotoxins are stable in the materials. Another twelve containers remained stored in the freezer. In addition, to mimic a possible thaw situation during transport, six containers were stored at room temperature for one day and then stored again in the freezer.

On June $5^{\text {th }}, 2017,43$ days after distribution of the samples, for each of the storage conditions $\left(<-70^{\circ} \mathrm{C}\right.$, freezer, one-day room temperature) six samples of materials $\mathrm{A}$ and $\mathrm{B}$ were analysed in one batch. For each set of test samples, the average of the results and the standard deviation were calculated.

It was determined whether a consequential instability of the analytes occurred $[11,12]$ in the materials stored in the freezer or stored at room temperature for one day. A consequential instability is observed when the average value of an analyte in the samples stored in the freezer or stored at room temperature for one day is more than $0.3 \sigma_{\mathrm{p}}$ below the average value of the analyte in the samples stored at $<-70^{\circ} \mathrm{C}$. If so, the instability has a significant influence on the calculated z-scores.

The results of the stability of materials $A$ and $B$ are presented in Annex 4. In none of the mycotoxin/storage condition combinations, a consequential difference was observed. The mycotoxins in the materials were therefore considered stable for the duration of the PT. 


\section{Organisational details}

\subsection{Participants}

This proficiency test focused on the mycotoxins DON, 3-Ac-DON, 15-Ac-DON and DON-3G in food and feed, using wheat. Invitations to the NRL network were sent out on $7^{\text {th }}$ of March 2018 (Annex 5). Fifty laboratories registered for the PT (Annex 1). This included 39 NRLs (38 from EU countries and one from Serbia), ten OLs, and one external laboratory. Each participant was asked a priori to indicate which compounds were included in the scope of their method. The participants were asked to report the results through an existing web application designed for proficiency tests organised by RIKILT.

\subsection{Material distribution and instructions}

Each of the participants received a randomly assigned laboratory code, generated by the web application. The sample sets with the corresponding number, consisting of two coded samples (Annex 2) were sent to the participants on April $23^{\text {th }}$ 2018. The sample sets were packed in an insulation box containing dry ice and were dispatched to the participants immediately by courier. The samples were accompanied by a letter describing the requested analysis (Annex 6) and an acknowledgement of receipt form. By e-mail the participants received instructions on how to use the web application to report the results.

The participants were asked to store the samples in the freezer and to analyse the samples according to their routine method. A single analysis result for the mycotoxins in each sample was requested. The deadline for submitting the quantitative results was June $4^{\text {th }}, 2018$, allowing the participants six weeks for the analysis.

All samples were received in good order by the participants. Results were submitted within the deadline with two exceptions. Participants PT052 and PT065 were unable to report results in time (a.o. due to instrument problems).

Participants were asked to provide information on their analysis method (extraction solvent/procedure, clean-up procedure, internal standards used, detection technique, limit of detection, limit of quantification). 


\section{$4 \quad$ Evaluation of results}

The statistical evaluation was carried out according to the International Harmonized Protocol for the Proficiency Testing of Analytical Laboratories [11], elaborated by ISO, IUPAC and AOAC and ISO 13528:2015 [12] in combination with the insights published by the Analytical Methods Committee $[13,14]$ regarding robust statistics.

The evaluation is based on assigned values and the standard deviation for proficiency assessment $(\sigma P)$. From this, z-scores are calculated to classify the participants' performance. Details on the methods used for the statistical evaluation can be found in the background document 'EURL-MP PT performance assessment' on the EURL-MP website.

\subsection{Calculation of the assigned value}

The consensus value based on the participants' results (NRLs and OLs) was used as the assigned value. The robust mean was used as consensus value in this PT. The values and their uncertainties are summarised in Table 1 in the summary section. Consensus values could be established for all analytes in both materials, except for 15-Ac-DON in material A (wheat) which was below the LOQ as used by the EURL-MP and below the LOQ of the majority of the participants.

\subsection{Standard deviation for proficiency assessment ( $\left.\sigma_{\mathrm{P}}\right)$}

A fixed relative target standard deviation for proficiency assessment of $25 \%$ was used, irrespective the mycotoxin, matrix or concentration. This generic fit-for-purpose value is considered to reflect current analytical capabilities and best practises for mycotoxin and plant toxin determination in food and feed. The rationale behind this is provided in the background document 'EURL-MP PT performance assessment' on the EURL-MP website.

\subsection{Quantitative performance (z-scores)}

For evaluation of numerical results submitted by the participant, z-scores are calculated based on the assigned value, its uncertainty, and the standard deviation for proficiency assessment $\left(\sigma_{P}\right)$. When the uncertainty of the assigned value is negligible and no instability of the analytes in the PT material is observed, z-scores are calculated by:

$z=\frac{x-C}{\sigma_{p}}$ Equation 1

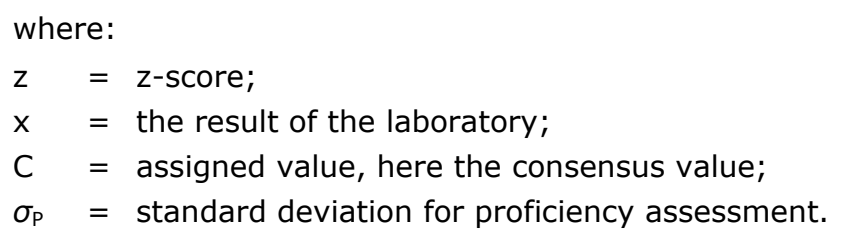

The z-score compares the participants' deviation from the assigned value, taking the target standard deviation accepted for the proficiency test into account, and is interpreted as indicated in Table 4. 


\begin{tabular}{cc}
\hline$|z| \leq 2$ & Satisfactory \\
\hline $2<|z|<3$ & Questionable \\
\hline$|z| \geq 3$ & Unsatisfactory \\
\hline
\end{tabular}

If not negligible, the uncertainty of the assigned value and, if applicable, instability of analytes in the PT material, are taken into account in the determination of the z-scores. If applicable, this is indicated by assigning a $z^{\prime}-, z_{i}{ }^{-}$, or $z_{i}^{\prime}$-score. For details see the background document 'EURL-MP PT performance assessment' on the EURL-MP website.

In this PT, the uncertainty of the assigned value for DON-3G in material A and 15-Ac-DON in material $B$ were not negligible and taken into account in the assignment of the $z$-score $\left(z^{\prime}\right)$. In all other cases, the uncertainty of the assigned value was negligible. No instability of the analytes in the PT material was observed.

\subsection{Evaluation of non-quantified results}

In case the participant reported ' $<$ [value]', i.e. below their limit of quantification (LOQ), 'proxy-zscores' were calculated as a way to assess possible false negatives and to benchmark the LOQ relative to the assigned value and the LOQ of the other participants.

A proxy-z-score was calculated by Equation 1, using the LOQ value as result. Proxy-z-scores are for information only and indicated as a value between brackets. Values below -2 are considered as false negatives (see 4.5). Values above 2 indicate that the LOQ is high in relation to the assigned value and high in comparison to other participants.

Other types of results, e.g. 'detected', or 'not detected' without specification of an LOQ, were excluded from the evaluation. In these cases the participant was considered not to have a quantitative method available for the applicable mycotoxin/matrix.

\subsection{False positives and false negatives}

A false positive is a quantitative result reported by the participant while the toxin is:

i) not detected in the PT material by the organiser, and/or

ii) not detected by the majority of the other participants.

A threshold may apply, below which results are not considered false positives, e.g. when the analyte concentration is below the LOQ of the organiser and/or the majority of the participants. This is decided on a case-to-case basis. False positives are indicated as ' $F P^{\prime}$ '. False positives are to be interpreted as unsatisfactory performance.

When an analyte is present in the material, i.e. an assigned value has been established, and the participant reports the analyte as ' $<$ [value]', and this value is well below the assigned value, then the result can be classified as a false negative. This is the case when the proxy-z-score (see 4.4 ) is $<-2$. False negatives are indicated as 'FN'. False negatives are to be interpreted as unsatisfactory performance. 


\section{Assessment of participants' performance}

\subsection{Scope and LOQ}

This PT was dedicated to DON, 3-Ac-DON, 15-Ac-DON and DON-3G. In Annex 7 the quantitative scope for each participant is provided, with indication of the LOQ provided. It was noted that three participants did not report results for the acetyl-DONs or DON-3G, despite the fact that these compounds were indicated to be in their scope during the a priori survey at the time of registration for the PT. While all laboratories have methods for determination of DON, only 22 out of 50 reported quantitative results for the acetyl-DONs, and only 16 out of 50 for DON-3G. Fourteen laboratories determined all four mycotoxins requested. The LOQs as provided by the participants varied widely, from low $\mu \mathrm{g} / \mathrm{kg}$ up to $500 \mu \mathrm{g} / \mathrm{kg}$. The median LOQs were $50 \mu \mathrm{g} / \mathrm{kg}$ for DON and DON-3G and $25 \mu \mathrm{g} / \mathrm{kg}$ for the acetyl-DONs.

There can be several causes for the gap in the scope observed for many laboratories. A first reason is that only DON is currently regulated, i.e. for analysis in the frame of enforcement inclusion of acetyl-DONs and DON-3G is not yet required. This could be a reason to not (yet) including the other DON forms in the method. Another reason might be that a number of laboratories are using methods involving an immuno-affinity-based clean-up (see 5.2) which may not be suited for simultaneous determination of all four toxins due to poor cross-reactivity [15]. Insight in the reasons for not covering the full scope will be obtained through a follow up questionnaire from the EURL-MP.

The quite extreme differences in LOQs may have several causes. The first is due to differences in analysis methods, i.e. different degrees of concentration factors of the final extract, and differences in sensitivity of (MS) instruments. Another cause may lie in the different ways that LOQs are defined and calculated. Finally, it can also not be excluded that in some cases the LOQ actually is a reporting limit, i.e. a cut-off value below which no results are reported, and is a rather arbitrary value below the regulatory limit but above the actual method LOQ.

Since NRLs are expected to have analytical capabilities not only in the frame of compliance testing of regulatory limits but also in the frame of data generation for risk assessment, efforts should be made toward inclusion of acetyl-DONs and DON-3G, and laboratories are recommended to aim for LOQs in the range of $\leq 50-100 \mu \mathrm{g} / \mathrm{kg}$ for DON, and $\leq 10-20 \mu \mathrm{g} / \mathrm{kg}$ for the three DON derivatives.

\subsection{Analysis methods}

Details on the analytical methods used by the participants are included in Annex 8 . The methods used can roughly be categorised in methods based on LC-MS/MS (two thirds), often without clean-up, and methods based on LC-UV (one third) with immunoaffinity column (IAC) clean-up. GC-MS was used by one laboratory.

LC-UV-based methods always involved a clean-up using IAC, and an extraction with water. In most cases, only DON was determined, although one laboratory also reported on all four analytes. The inclusion of other DON derivatives besides DON itself with methods involving IAC clean-up might be difficult as IAC columns often have no or limited cross-reactivity for the DON derivatives [15].

In LC-MS/MS based methods extraction was mostly done using acetonitrile/water (23x), with or without acidification (acetic acid or formic acid). In six cases a salt-induced phase partitioning was done (QuEChERS type of extraction/clean-up). Methanol/water was used by three laboratories. In many cases no clean-up was performed, apart from a phase partitioning in case of QuEChERS-based approaches, or a dilution of the extract. When a clean-up was included, this was by solid phase 
extraction (SPE, $8 \mathrm{x}$ ) or by IAC $(4 \mathrm{x})$. Fourteen laboratories used isotopically labelled internal standards, in most cased only for DON. Despite the good possibilities to cover all forms of DON in LC-MS/MS-based methods, ten laboratories reported only DON.

Based on the results and method details provided by the laboratories, no obvious effects of extraction, clean-up or measurement methods on the results were observed.

\subsection{Performance}

The quantitative performance was assessed through z-scores. For each participant, the individual z-scores for the mycotoxins in material A (wheat) and B (maize) are provided in Annex 9 and 10, respectively. These annexes also show graphical representations of the z-scores.

For DON satisfactory z-scores were obtained by almost all participants in both materials. There were only two exceptions (one NRL and one OL). Combining the results for the two materials, $97 \%$ of the z-scores were satisfactory.

As indicated in 5.1, 22 out of the 50 laboratories determined the acetyl-DONs. For 3-Ac-DON in total five unacceptable z-scores were observed, mostly for wheat that contained the lower concentration. 15-Ac-DON was not present in material $A(<R L[20 \mu / \mathrm{kg}]$ used by the EURL, indicative level $6 \mu \mathrm{g} / \mathrm{kg})$. $15-A c-D O N$ was quantified in this material above $20 \mu \mathrm{g} / \mathrm{kg}$ by four laboratories. Those results were classified as false positives. In material B, 15-Ac-DON was present at $154 \mu \mathrm{g} / \mathrm{kg}$ but reported as below LOQ by two laboratories. As the assigned value was well above their LOQs, these results were classified as false negatives. Besides the false negatives, unsatisfactory performance was observed for one other laboratory (z-score $>3$ ). Combining the results for both acetyl-DONs in both materials, $81 \%$ of the z-scores were satisfactory (here the false positives were considered as unsatisfactory). The poorer performance for the acetyl-DONs may be due to difficulties in the chromatographic analysis. 3-Ac-DON and 15-Ac-DON are often co-eluting under generic chromatographic conditions which makes their determination less straightforward. However, it is possible to separate them chromatographically, and to a certain extend also mass spectrometrically (details see [10]).

DON-3G was included in the analysis by 16 out of the 50 laboratories. In general satisfactory z-scores were obtained in both materials, although due to the relatively low level in material B (maize, $35 \mu \mathrm{g} / \mathrm{kg}$ ) only eleven laboratories could quantify this DON conjugate.

A summary of the characteristics and performance of the participants in this PT for each mycotoxins in each material is provided in Table 1 in the Summary.

In Annex 11 an overview is given of the overall performance for each participant in this PT. For the two materials combined, a maximum of seven satisfactory z-scores could be obtained, and ' 7 out of 7 ' reflects optimal performance in terms of scope and capability for quantitative determination. The number of laboratories that analysed the materials for all four mycotoxins was fourteen. Of these, seven achieved optimal performance. For the other seven, either the LOQ was too high, false positives or false negatives were reported, or a non-satisfactory z-score was obtained.

\subsection{Robust relative standard deviation}

For informative purposes the robust standard deviation $\left(\mathrm{RSD}_{\mathrm{R}}\right)$ was calculated according to ISO13528:2015 [12]. This provides a good estimation of the interlaboratory variability. The individual $\mathrm{RSD}_{\mathrm{R}}$ values for each toxin in both materials are included in Annex 9 and 10, and also in Table 1. They ranged from $14 \%$ for DON-3G in material B (35 $\mathrm{gg} / \mathrm{kg})$ to $28 \%$ for DON-3G in material A (209 $\mu \mathrm{g} / \mathrm{kg})$. 


\section{Conclusions}

Fifty laboratories, including NRLs from all member states, participated in EURL-PT-MP01 on the quantitative determination of DON, 3-Ac-DON, 15-Ac-DON and DON-3G in cereals (wheat and maize). All laboratories determined DON, but only $44 \%$ included the acetyl-DONs, and only 32\% DON-3G. Fourteen laboratories analysed the materials for all four target toxins. LOQs varied widely from low $\mu \mathrm{g} / \mathrm{kg}$ to $500 \mu \mathrm{g} / \mathrm{kg}$ (medians in the range $25-50 \mu \mathrm{g} / \mathrm{kg}$ ). LOQs were generally adequate for compliance testing for DON, but not always for monitoring in the frame of risk assessment.

Two-thirds of the laboratories used methods based on LC-MS/MS, either with or without clean-up. One third used methods based on LC-UV with IAC as clean-up step.

For DON satisfactory results were obtained in almost all cases. For the other three mycotoxins satisfactory performance rates were lower, $81 \%$ for the acetyl-DONs and $89 \%$ for DON-3G. Only seven out of 50 laboratories obtained satisfactory performance for all four toxins.

The quantitative performance of the participants was generally good, but extension of the scope is needed in many cases (and lower LOQs in some) to align with EFSA monitoring recommendations. In a relatively limited number of cases, a follow up is needed regarding questionable or unsatisfactory z-scores and false positive/false negative results. 


\section{References}

[1] EFSA CONTAM Panel (EFSA Panel on Contaminants in the Food Chain), Knutsen HK et al. Scientific Opinion on the risks to human and animal health related to the presence of deoxynivalenol and its acetylated and modified forms in food and feed. EFSA Journal 2017;15(9):4718, $345 \mathrm{pp}$.

[2] Commission Regulation (EC) No 1881/2006 of 19 December 2006 setting maximum levels for certain contaminants in foodstuffs. Official Journal of the European Union. L 364/5.

[3] Commission Recommendation 2006/576/EC of 17 August 2006 on the presence of deoxynivalenol, zearalenone, ochratoxin A, T-2 and HT-2 and fumonisins in products intended for animal feeding. Official Journal of the European Union. L 229/7.

[4] EC 2013 Compilation of agreed monitoring recommendations as regards the presence of mycotoxins and plant toxins in food.

https://ec.europa.eu/food/sites/food/files/safety/docs/cs_monitoring_recommendations_en.pdf

[5] Council Directive 93/99/EEC of 29 October 1993 on the subject of additional measures concerning the official control of foodstuffs. Official Journal $L 290,24 / 11 / 1993,14-17$.

[6] ISO/IEC 17025:2017(E). 2017. General requirements for the competence of testing and calibration laboratories.

[7] Regulation (EU) 2017/625 on official controls and other official activities performed to ensure the application of food and feed law, rules on animal health and welfare, plant health and plant protection products, Art. 94.2. Official J. of the European Union 7.4.2017, L95, 1-142. https://eur-lex.europa.eu/legal-content/EN/TXT/PDF/?uri=CELEX:32017R0625\&from=EN

[8] ISO/IEC 17043:2010. 2010. Conformity assessment - General requirements for proficiency testing.

[9] RIKILT SOP-A0989 - Preparation of PT materials and PT samples.

[10] EURL-MP-method_001 v1, 2018, Determination of deoxynivalenol and related compounds in cereals by LC-MS/MS, EURL mycotoxins and plant toxins, RIKILT Wageningen University \& Research. https://www.wur.nl/upload_mm/3/a/2/89801fc3-9656-44b6-989c-61b0c7cc6ef9_EURL-MPmethod_001\%20DON\%20and\%20related\%20compounds\%20by\%20LC-MS-MS\%20v1.pdf

[11] Thompson M, Ellison SL, Wood R. 2006. The International Harmonized Protocol for the Proficiency Testing of Analytical Chemistry Laboratories. Pure Appl. Chem. 78(1):145-196.

[12] ISO 13528:2015. Statistical methods for use in proficiency testing by inter-laboratory comparison, 1st edition.

[13] Analytical Methods Committee. 1989. Robust statistics - How not to reject outliers Part 1. Basic concepts. Analyst 114:1693-1697.

[14] Analytical Methods Committee. 1989. Robust statistics - How not to reject outliers Part 2. Inter-laboratory trials. Analyst. 114:1699-1702.

[15] Versilovskis A, Huybrecht B, Tangni EK, Pussemier L, De Saeger S, Callebaut A, Crossreactivity of some commercially available deoxynivalenol (DON) and zearalenone (ZEN) immunoaffinity columns to DON and ZEN-conjugated forms and metabolites. Food Additives and Contam. 28 (2011) 1687-1693. 


\section{Annex 1 List of participants}

\begin{tabular}{|c|c|}
\hline Country & Organisation \\
\hline AUSTRIA* & AGES Austrian Agency for Health and Food Safety \\
\hline AUSTRIA & University of Natural Resources and Life Sciences Vienna (BOKU) \\
\hline BELGIUM* & Sciensano (pka Veterinary and Agrochemical Research Centre (CODA-CERVA)) \\
\hline BULGARIA* & Bulgarian Food Safety Agency \\
\hline CROATIA* & Andrija Stampar Teaching Institute of Public Health \\
\hline CYPRUS* & Feeding Stuffs Quality Control Laboratory \\
\hline CYPRUS* & State General Laboratory \\
\hline CZECH REPUBLIC* & Central Institute for Supervising and Testing in Agriculture (UKZUZ) \\
\hline CZECH REPUBLIC* & Czech Agriculture and Food Inspection Authority (CAFIA) \\
\hline DENMARK* & Danish Veterinary and Food Administration \\
\hline DENMARK* & National Food Institute \\
\hline ESTONIA* & Agricultural Research Centre \\
\hline FINLAND* & Finnish Customs Laboratory \\
\hline FINLAND* & Finnish Food Safety Authority Evira \\
\hline FINLAND & Natural Resources Institute Finland \\
\hline FRANCE & LABOCEA \\
\hline FRANCE & Laboratoires des Pyrenees et des Landes \\
\hline FRANCE* & Service Commun des Laboratoires DGCCRF-DGDDI (SCL-L35) Laboratoire de RENNES \\
\hline GERMANY* & Federal Institute fur Risk Assessment (BfR) \\
\hline GREECE* & General Chemical State Laboratory (GCSL) \\
\hline HUNGARY* & National Food Chain Safety Office, Analytical NRL \\
\hline HUNGARY* & National Food Chain Safety Office, Toxicological NRL \\
\hline IRELAND* & Public Analyst's Laboratory (HSE) \\
\hline IRELAND* & The State Laboratory \\
\hline ITALY & ARPA FVG \\
\hline ITALY & ARPAM \\
\hline ITALY & ATS MILANO \\
\hline ITALY* & Istituto Superiore di Sanita (ISS) \\
\hline LATVIA* & Institute of Food Safety, Animal Health and Environment (BIOR) \\
\hline LITHUANIA* & National Food and Veterinary Risk Assessment Institute \\
\hline LUXEMBOURG* & Laboratoire National de Santé surveillance alimentaire \\
\hline MALTA* & Public Health Laboratory \\
\hline NETHERLANDS & Nederlandse Voedsel en Waren Autoriteit \\
\hline POLAND* & National Institute of Public Health - National Institute of Hygiene \\
\hline POLAND* & National Veterinary Research Institute \\
\hline PORTUGAL* & Autoridade Seguranca Alimentar e Economica \\
\hline ROMANIA* & Directia Sanitara Veterinara si pentru Siguranta Alimentelor (DSVSA) Bucuresti \\
\hline ROMANIA* & Hygiene and Veterinary Public Health Institute \\
\hline SERBIA & SP Laboratorija A.D. \\
\hline SLOVAKIA* & Regional Public Health Authority in Poprad (RUVZ) \\
\hline SLOVAKIA* & State veterinary and food institute \\
\hline SLOVENIA* & National laboratory of health, environment and food \\
\hline SLOVENIA* & University of Ljubljana, Veterinary Faculty, National Veterinary Institute \\
\hline SPAIN & AINIA \\
\hline SPAIN & Laboratori Agroalimentari \\
\hline SPAIN* & National Center for Food (AESAN) \\
\hline SWEDEN* & National Food Agency (SLV) \\
\hline SWEDEN* & National Veterinary Institute (SVA) \\
\hline UNITED KINGDOM* & Fera Science Ltd \\
\hline UNITED KINGDOM & Public Analyst Scientific Services Limited \\
\hline
\end{tabular}




\section{Annex 2 Codification of the samples}

\begin{tabular}{|c|c|c|c|c|c|}
\hline $\begin{array}{c}\text { Participants } \\
\text { code }\end{array}$ & Material A* & Material B* & $\begin{array}{l}\text { Participants } \\
\text { code }\end{array}$ & Material A* & Material B* \\
\hline РT031 & 837 & 137 & PT056 & 274 & 922 \\
\hline РT032 & 561 & 169 & PT057 & 247 & 847 \\
\hline РT033 & 703 & 916 & PT058 & 228 & 583 \\
\hline РT034 & 426 & 431 & PT059 & 366 & 593 \\
\hline РT035 & 269 & 224 & PT060 & 104 & 972 \\
\hline РT036 & 344 & 321 & PT061 & 181 & 463 \\
\hline РT037 & 724 & 205 & PT062 & 663 & 377 \\
\hline РT038 & 885 & 616 & PT063 & 795 & 386 \\
\hline РT039 & 596 & 352 & PT064 & 311 & 612 \\
\hline РT040 & 782 & 808 & PT065 & 642 & 166 \\
\hline РT041 & 409 & 539 & PT066 & 361 & 995 \\
\hline РT042 & 552 & 405 & PT067 & 400 & 290 \\
\hline РT043 & 154 & 468 & PT068 & 354 & 500 \\
\hline РT044 & 737 & 615 & PT069 & 842 & 245 \\
\hline PT045 & 515 & 991 & PT070 & 110 & 200 \\
\hline РT046 & 220 & 665 & PT071 & 326 & 342 \\
\hline РT047 & 850 & 647 & PT072 & 139 & 327 \\
\hline РT048 & 419 & 542 & PT073 & 393 & 280 \\
\hline РT049 & 824 & 691 & PT074 & 576 & 293 \\
\hline РT050 & 499 & 252 & PT075 & 757 & 168 \\
\hline РT051 & 261 & 216 & PT076 & 626 & 720 \\
\hline РT052 & 902 & 731 & PT077 & 516 & 793 \\
\hline РT053 & 867 & 861 & PT9958 & 775 & 889 \\
\hline РT054 & 268 & 451 & РT9959 & 491 & 638 \\
\hline PT055 & 575 & 978 & PT9960 & 316 & 246 \\
\hline
\end{tabular}

* All sample codes start with EURLPT-MP 01/. 


\section{Annex 3 Statistical evaluation of homogeneity data}

\begin{tabular}{|c|c|c|}
\hline \multirow[b]{2}{*}{ Sample No. } & \multicolumn{2}{|c|}{ DON in A $(\mu \mathrm{g} / \mathrm{kg})$} \\
\hline & Replicate 1 & Replicate $\mathbf{2}$ \\
\hline Hom/A001 & 613 & 560 \\
\hline Hom/A002 & 550 & 536 \\
\hline Hom/A003 & 550 & 518 \\
\hline Hom/A004 & 533 & 520 \\
\hline Hom/A005 & 550 & 525 \\
\hline Hom/A006 & 580 & 557 \\
\hline Hom/A007 & 521 & 493 \\
\hline Hom/A008 & 532 & 516 \\
\hline Hom/A009 & 506 & 523 \\
\hline Hom/A010 & 530 & 502 \\
\hline Grand mean & \multicolumn{2}{|c|}{536} \\
\hline \multicolumn{3}{|l|}{ Cochran's test } \\
\hline C & \multicolumn{2}{|c|}{0.377} \\
\hline Ccrit & \multicolumn{2}{|c|}{0.602} \\
\hline$C<$ Ccrit? & \multicolumn{2}{|c|}{ NO OUTLIERS } \\
\hline Target $\mathrm{s}=\sigma_{\mathrm{p}}$ & \multicolumn{2}{|c|}{134} \\
\hline$S_{x}$ & \multicolumn{2}{|c|}{25.0} \\
\hline $\mathrm{S}_{\mathrm{w}}$ & \multicolumn{2}{|c|}{19.2} \\
\hline $\mathrm{S}_{\mathrm{s}}$ & \multicolumn{2}{|c|}{21.0} \\
\hline Critical $=0.3 \sigma_{p}$ & \multicolumn{2}{|c|}{40.2} \\
\hline $\mathrm{S}_{\mathrm{s}}<$ critical? & \multicolumn{2}{|c|}{ ACCEPTED } \\
\hline $\mathrm{S}_{\mathrm{w}}<0.5 \sigma_{\mathrm{p}} ?$ & \multicolumn{2}{|c|}{ ACCEPTED } \\
\hline
\end{tabular}

$\mathrm{s}_{\mathrm{x}}=$ Standard deviation of the sample averages.

$\mathrm{S}_{\mathrm{w}}=$ Within-sample standard deviation.

$\mathrm{S}_{\mathrm{s}}=$ Between-sample standard deviation .

\begin{tabular}{|c|c|c|}
\hline \multirow[b]{2}{*}{ Sample No. } & \multicolumn{2}{|c|}{ 3-AC-DON in A $(\mu \mathrm{g} / \mathrm{kg})$} \\
\hline & Replicate 1 & Replicate 2 \\
\hline Hom/A001 & 33.1 & 31.7 \\
\hline Hom/A003 & 30.4 & 32.0 \\
\hline Hom/A004 & 31.7 & 32.3 \\
\hline Hom/A007 & 30.6 & 31.8 \\
\hline Hom/A008 & 32.6 & 31.6 \\
\hline Hom/A009 & 30.1 & 30.4 \\
\hline Hom/A010 & 31.5 & 32.8 \\
\hline Ccrit & \multicolumn{2}{|c|}{0.602} \\
\hline$C<$ Ccrit? & \multicolumn{2}{|c|}{ NO OUTLIERS } \\
\hline Target $\mathrm{s}=\sigma_{\mathrm{P}}$ & \multicolumn{2}{|c|}{7.96} \\
\hline$s_{x}$ & \multicolumn{2}{|c|}{0.752} \\
\hline $\mathrm{S}_{\mathrm{w}}$ & \multicolumn{2}{|c|}{0.763} \\
\hline $\mathrm{S}_{\mathrm{s}}$ & \multicolumn{2}{|c|}{0.524} \\
\hline Critical $=0.3 \sigma_{p}$ & \multicolumn{2}{|c|}{2.39} \\
\hline $\mathrm{S}_{\mathrm{s}}<$ critical $?$ & \multicolumn{2}{|c|}{ ACCEPTED } \\
\hline $\mathrm{S}_{\mathrm{w}}<0.5 \sigma_{\mathrm{p}} ?$ & \multicolumn{2}{|c|}{ ACCEPTED } \\
\hline
\end{tabular}

$\mathrm{s}_{\mathrm{x}}=$ Standard deviation of the sample averages.

$\mathrm{S}_{\mathrm{w}}=$ Within-sample standard deviation.

$\mathrm{s}_{\mathrm{s}}=$ Between-sample standard deviation. 


\begin{tabular}{|c|c|c|}
\hline \multirow[b]{2}{*}{ Sample No. } & \multicolumn{2}{|c|}{ DON-3G in A $(\mu \mathrm{g} / \mathrm{kg})$} \\
\hline & Replicate 1 & Replicate 2 \\
\hline Hom/A001 & 316 & 247 \\
\hline Hom/A002 & 249 & 262 \\
\hline Hom/A003 & 261 & 250 \\
\hline Hom/A004 & 261 & 267 \\
\hline Hom/A005 & 235 & 266 \\
\hline Hom/A006 & 292 & 254 \\
\hline Hom/A007 & 253 & 255 \\
\hline Hom/A008 & 252 & 260 \\
\hline Hom/A009 & 277 & 249 \\
\hline Hom/A010 & 251 & 271 \\
\hline Grand mean & \multicolumn{2}{|c|}{261} \\
\hline \multicolumn{3}{|l|}{ Cochran's test } \\
\hline C & \multicolumn{2}{|c|}{0.546} \\
\hline Ccrit & \multicolumn{2}{|c|}{0.602} \\
\hline$C<$ Ccrit? & \multicolumn{2}{|c|}{ NO OUTLIERS } \\
\hline Target $\mathrm{S}=\sigma_{\mathrm{P}}$ & \multicolumn{2}{|c|}{65.3} \\
\hline$s_{x}$ & \multicolumn{2}{|c|}{9.58} \\
\hline $\mathrm{S}_{w}$ & \multicolumn{2}{|c|}{20.9} \\
\hline $\mathrm{S}_{\mathrm{s}}$ & \multicolumn{2}{|c|}{0.00} \\
\hline Critical $=0.3 \sigma_{\mathrm{P}}$ & \multicolumn{2}{|c|}{19.6} \\
\hline $\mathrm{s}_{\mathrm{s}}<$ critical? & \multicolumn{2}{|c|}{ ACCEPTED } \\
\hline $\mathrm{s}_{\mathrm{W}}<0.5 \sigma_{H} ?$ & \multicolumn{2}{|c|}{ ACCEPTED } \\
\hline
\end{tabular}

$\mathrm{s}_{\mathrm{x}}=$ Standard deviation of the sample averages.

$\mathrm{S}_{\mathrm{w}}=$ Within-sample standard deviation.

$\mathrm{S}_{\mathrm{s}}=$ Between-sample standard deviation.

\begin{tabular}{|c|c|c|}
\hline \multirow[b]{2}{*}{ Sample No. } & \multicolumn{2}{|c|}{ DON in B $(\mu \mathrm{g} / \mathrm{kg})$} \\
\hline & Replicate 1 & Replicate 2 \\
\hline Hom/B001 & 787 & 806 \\
\hline Hom/B002 & 762 & 785 \\
\hline Hom/B003 & 756 & 720 \\
\hline Hom/B004 & 685 & 745 \\
\hline Hom/B005 & 741 & 765 \\
\hline Hom/B006 & 745 & 740 \\
\hline Hom/B007 & 719 & 703 \\
\hline Hom/B008 & 693 & 696 \\
\hline Hom/B009 & 642 & 676 \\
\hline Hom/B010 & 706 & 733 \\
\hline Grand mean & \multicolumn{2}{|c|}{730} \\
\hline \multicolumn{3}{|l|}{ Cochran's test } \\
\hline C & \multicolumn{2}{|c|}{0.422} \\
\hline Ccrit & \multicolumn{2}{|c|}{0.602} \\
\hline$C<$ Ccrit? & \multicolumn{2}{|c|}{ NO OUTLIERS } \\
\hline Target $\mathrm{s}=\sigma_{\mathrm{P}}$ & \multicolumn{2}{|c|}{183} \\
\hline $\mathrm{s}_{\mathrm{x}}$ & \multicolumn{2}{|c|}{39.5} \\
\hline $\mathrm{S}_{\mathrm{w}}$ & \multicolumn{2}{|c|}{20.8} \\
\hline $\mathrm{S}_{\mathrm{s}}$ & \multicolumn{2}{|c|}{36.6} \\
\hline Critical $=0.3 \sigma_{\mathrm{P}}$ & \multicolumn{2}{|c|}{54.8} \\
\hline $\mathrm{s}_{\mathrm{s}}<$ critical? & \multicolumn{2}{|c|}{ ACCEPTED } \\
\hline $\mathrm{S}_{\mathrm{W}}<0.5 \sigma_{H} ?$ & \multicolumn{2}{|c|}{ ACCEPTED } \\
\hline
\end{tabular}

$\mathrm{s}_{\mathrm{x}}=$ Standard deviation of the sample averages.

$\mathrm{S}_{\mathrm{w}}=$ Within-sample standard deviation.

$\mathrm{s}_{\mathrm{s}}=$ Between-sample standard deviation. 


\begin{tabular}{|c|c|c|}
\hline \multirow[b]{2}{*}{ Sample No. } & \multicolumn{2}{|c|}{ 3-Ac-DON in B $(\mu \mathrm{g} / \mathrm{kg})$} \\
\hline & Replicate 1 & Replicate 2 \\
\hline Hom/B001 & 103 & 98.9 \\
\hline Hom/B002 & 102 & 101 \\
\hline Hom/B003 & 100 & 105 \\
\hline Hom/B004 & 88.4 & 98.0 \\
\hline Hom/B005 & 96.0 & 99.2 \\
\hline Hom/B006 & 99.4 & 98.4 \\
\hline Hom/B007 & 96.2 & 101 \\
\hline Hom/B008 & 95.2 & 92.2 \\
\hline Hom/B009 & 99.5 & 102 \\
\hline Hom/B010 & 96.7 & 104 \\
\hline Grand mean & \multicolumn{2}{|c|}{98.8} \\
\hline \multicolumn{3}{|l|}{ Cochran's test } \\
\hline C & \multicolumn{2}{|c|}{0.388} \\
\hline Ccrit & \multicolumn{2}{|c|}{0.602} \\
\hline$C<$ Ccrit? & \multicolumn{2}{|c|}{ NO OUTLIERS } \\
\hline Target $\mathrm{S}=\sigma_{\mathrm{P}}$ & \multicolumn{2}{|c|}{24.7} \\
\hline$s_{x}$ & \multicolumn{2}{|c|}{3.15} \\
\hline $\mathrm{S}_{w}$ & \multicolumn{2}{|c|}{3.43} \\
\hline $\mathrm{S}_{\mathrm{s}}$ & \multicolumn{2}{|c|}{2.01} \\
\hline Critical $=0.3 \sigma_{p}$ & \multicolumn{2}{|c|}{7.41} \\
\hline $\mathrm{S}_{\mathrm{s}}<$ critical? & \multicolumn{2}{|c|}{ ACCEPTED } \\
\hline $\mathrm{s}_{\mathrm{W}}<0.5 \sigma_{H} ?$ & \multicolumn{2}{|c|}{ ACCEPTED } \\
\hline
\end{tabular}

$\mathrm{S}_{\mathrm{x}}=$ Standard deviation of the sample averages.

$\mathrm{S}_{\mathrm{w}}=$ Within-sample standard deviation.

$\mathrm{s}_{\mathrm{s}}=$ Between-sample standard deviation

\begin{tabular}{|c|c|c|}
\hline Sample No. & \multicolumn{2}{|c|}{$15-A C-D O N$ in $B(\mu g / k g)$} \\
\hline Hom/B001 & 161 & 158 \\
\hline Hom/B003 & 143 & 146 \\
\hline Hom/B004 & 142 & 139 \\
\hline Hom/B006 & 156 & 143 \\
\hline Hom/B007 & 136 & 134 \\
\hline Hom/B008 & 127 & 116 \\
\hline Hom/B009 & 126 & 146 \\
\hline Hom/B010 & 152 & 167 \\
\hline Ccrit & \multicolumn{2}{|c|}{0.602} \\
\hline$C<$ Ccrit? & \multicolumn{2}{|c|}{ NO OUTLIERS } \\
\hline Target $\mathrm{s}=\sigma_{\mathrm{p}}$ & \multicolumn{2}{|c|}{36.1} \\
\hline $\mathrm{s}_{\mathrm{x}}$ & \multicolumn{2}{|c|}{11.6} \\
\hline $\mathrm{S}_{\mathrm{w}}$ & \multicolumn{2}{|c|}{7.18} \\
\hline $\mathrm{Ss}$ & \multicolumn{2}{|c|}{10.4} \\
\hline Critical $=0.3 \sigma_{p}$ & \multicolumn{2}{|c|}{10.8} \\
\hline $\mathrm{S}_{\mathrm{s}}<$ critical $?$ & \multicolumn{2}{|c|}{ ACCEPTED } \\
\hline $\mathrm{S}_{\mathrm{W}}<0.5 \sigma_{\mathrm{H}} ?$ & \multicolumn{2}{|c|}{ ACCEPTED } \\
\hline
\end{tabular}

$\mathrm{S}_{\mathrm{x}}=$ Standard deviation of the sample averages.

$\mathrm{S}_{\mathrm{w}}=$ Within-sample standard deviation.

$\mathrm{s}_{\mathrm{s}}=$ Between-sample standard deviation 


\begin{tabular}{|c|c|c|}
\hline \multirow[b]{2}{*}{ Sample No. } & \multicolumn{2}{|c|}{ DON-3G in B ( $\mu g / k g)$} \\
\hline & Replicate 1 & Replicate 2 \\
\hline Hom/B001 & 24.8 & 24.2 \\
\hline Hom/B002 & 25.0 & 25.1 \\
\hline Hom/B003 & 22.2 & 26.1 \\
\hline Hom/B004 & 25.6 & 24.7 \\
\hline Hom/B005 & 23.6 & 25.1 \\
\hline Hom/B006 & 25.6 & 29.4 \\
\hline Hom/B007 & 19.4 & 23.9 \\
\hline Hom/B008 & 23.7 & 28.7 \\
\hline Hom/B009 & 24.6 & 25.6 \\
\hline Hom/B010 & 23.5 & 27.2 \\
\hline Grand mean & \multicolumn{2}{|c|}{24.9} \\
\hline \multicolumn{3}{|l|}{ Cochran's test } \\
\hline C & \multicolumn{2}{|c|}{0.272} \\
\hline Ccrit & \multicolumn{2}{|c|}{0.602} \\
\hline$C<$ Ccrit? & \multicolumn{2}{|c|}{ NO OUTLIERS } \\
\hline Target $\mathrm{s}=\sigma_{\mathrm{P}}$ & \multicolumn{2}{|c|}{6.22} \\
\hline$s_{x}$ & \multicolumn{2}{|c|}{1.51} \\
\hline $\mathrm{S}_{w}$ & \multicolumn{2}{|c|}{2.16} \\
\hline $\mathrm{S}_{\mathrm{s}}$ & \multicolumn{2}{|c|}{0.00} \\
\hline Critical $=0.3 \sigma_{\mathrm{p}}$ & \multicolumn{2}{|c|}{1.87} \\
\hline $\mathrm{s}_{\mathrm{s}}<$ critical? & \multicolumn{2}{|c|}{ ACCEPTED } \\
\hline $\mathrm{s}_{\mathrm{w}}<0.5 \sigma_{\mathrm{H}} ?$ & \multicolumn{2}{|c|}{ ACCEPTED } \\
\hline
\end{tabular}

$\mathrm{S}_{\mathrm{x}}=$ Standard deviation of the sample averages.

$\mathrm{S}_{\mathrm{w}}=$ Within-sample standard deviation.

$\mathrm{s}_{\mathrm{s}}=$ Between-sample standard deviation 


\section{Annex 4 Statistical evaluation of stability data}

Stability evaluation for DON in material A.

\begin{tabular}{cccc} 
Storage temperature & $<-70^{\circ} \mathrm{C}$ & $<-18{ }^{\circ} \mathrm{C}$ & 1 day RT \\
Time (days) & 0 & 43 & 43 \\
\hline Calculated amounts $(\mu \mathrm{g} / \mathrm{kg})$ & 507 & 491 & 501 \\
& 532 & 527 & 517 \\
& 497 & 517 & 506 \\
& 531 & 518 & 513 \\
Average amount $(\mu \mathrm{g} / \mathrm{kg})$ & 512 & 503 & 507 \\
$\mathrm{n}$ & 508 & 510 & 493 \\
\hline st. dev $(\mu \mathrm{g} / \mathrm{kg})$ & 514 & 511 & 506 \\
Difference & 6 & 6 & 6 \\
$0.3 * \sigma_{\mathrm{p}}$ & 14.1 & 12.6 & 3.66 \\
\hline Consequential difference? Diff $<0.3 * \sigma_{\mathrm{p}}$ & & 38.6 & 7.91 \\
\end{tabular}

Stability evaluation for 3-AC-DON in material $\boldsymbol{A}$.

\begin{tabular}{|c|c|c|c|}
\hline Storage temperature & $<-70^{\circ} \mathrm{C}$ & $<-18^{\circ} \mathrm{C}$ & 1 day $R T$ \\
\hline Time (days) & 0 & 43 & 43 \\
\hline \multirow[t]{6}{*}{ Calculated amounts $(\mu \mathrm{g} / \mathrm{kg})$} & 28.8 & 35.2 & 32.6 \\
\hline & 31.3 & 31.3 & 30.8 \\
\hline & 33.1 & 33.1 & 30.8 \\
\hline & 32.4 & 29.0 & 31.2 \\
\hline & 28.5 & 31.9 & 34.5 \\
\hline & 29.8 & 31.9 & 31.9 \\
\hline Average amount $(\mu \mathrm{g} / \mathrm{kg})$ & 30.6 & 32.1 & 31.9 \\
\hline $\mathrm{n}$ & 6 & 6 & 6 \\
\hline st. dev $(\mu \mathrm{g} / \mathrm{kg})$ & 1.93 & 2.03 & 1.42 \\
\hline Difference & & -1.44 & -1.32 \\
\hline $0.3^{*} \sigma_{p}$ & & 2.30 & 2.30 \\
\hline Consequential difference? Diff $<0.3^{*} \sigma_{p}$ & & No & No \\
\hline
\end{tabular}

Stability evaluation for DON-3-G in material A.

\begin{tabular}{|c|c|c|c|}
\hline Storage temperature & $<-70^{\circ} \mathrm{C}$ & $<-18^{\circ} \mathrm{C}$ & 1 day RT \\
\hline Time (days) & 0 & 43 & 43 \\
\hline \multirow[t]{6}{*}{ Calculated amounts $(\mu \mathrm{g} / \mathrm{kg})$} & 249 & 242 & 236 \\
\hline & 253 & 256 & 251 \\
\hline & 240 & 260 & 260 \\
\hline & 253 & 248 & 241 \\
\hline & 240 & 231 & 241 \\
\hline & 244 & 230 & 235 \\
\hline Average amount $(\mu \mathrm{g} / \mathrm{kg})$ & 247 & 245 & 244 \\
\hline $\mathrm{n}$ & 6 & 6 & 6 \\
\hline st. dev $(\mu \mathrm{g} / \mathrm{kg})$ & 6.18 & 12.5 & 9.50 \\
\hline Difference & & 2.00 & 2.81 \\
\hline $0.3 * \sigma_{p}$ & & 18.5 & 18.5 \\
\hline Consequential difference? Diff $<0.3^{*} \sigma_{p}$ & & No & No \\
\hline
\end{tabular}


Stability evaluation for DON in material B.

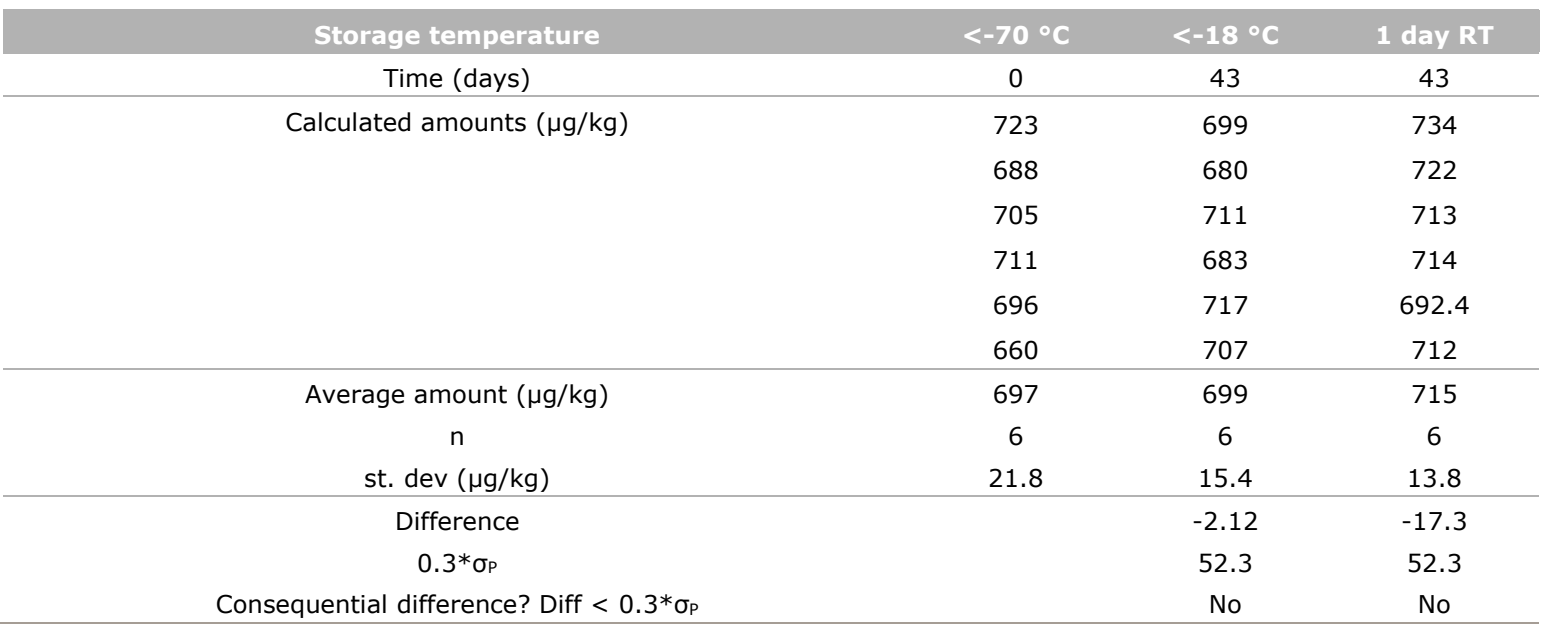

Statistical evaluation for 3-AC-DON in material B.

\begin{tabular}{|c|c|c|c|}
\hline Storage temperature & $<-70^{\circ} \mathrm{C}$ & $<-18{ }^{\circ} \mathrm{C}$ & 1 day RT \\
\hline Time (days) & 0 & 43 & 43 \\
\hline \multirow[t]{4}{*}{ Calculated amounts $(\mu \mathrm{g} / \mathrm{kg})$} & 99 & 98 & 90 \\
\hline & 100 & 95 & 95 \\
\hline & 91 & 103 & 101 \\
\hline & 96 & 99 & 95 \\
\hline Average amount $(\mu \mathrm{g} / \mathrm{kg})$ & 97 & 98 & 97 \\
\hline $\mathrm{n}$ & 6 & 6 & 6 \\
\hline st. $\operatorname{dev}(\mu \mathrm{g} / \mathrm{kg})$ & 3.56 & 3.87 & 4.48 \\
\hline
\end{tabular}

Statistical evaluation for 15-AC-DON in material B.

\begin{tabular}{|c|c|c|c|}
\hline Storage temperature & $<-70^{\circ} \mathrm{C}$ & $<-18^{\circ} \mathrm{C}$ & 1 day RT \\
\hline Time (days) & 0 & 43 & 43 \\
\hline \multirow[t]{4}{*}{ Calculated amounts $(\mu \mathrm{g} / \mathrm{kg})$} & 169 & 155 & 162 \\
\hline & 168 & 163 & 156 \\
\hline & 172 & 168 & 167 \\
\hline & 154 & 158 & 153 \\
\hline Average amount $(\mu \mathrm{g} / \mathrm{kg})$ & 164 & 160 & 159 \\
\hline $\mathrm{n}$ & 6 & 6 & 6 \\
\hline st. dev $(\mu \mathrm{g} / \mathrm{kg})$ & 7.41 & 6.21 & 4.57 \\
\hline
\end{tabular}




\section{Statistical evaluation for DON-3G in material B.}

\begin{tabular}{|c|c|c|c|}
\hline Storage temperature & $<-70^{\circ} \mathrm{C}$ & $<-18^{\circ} \mathrm{C}$ & 1 day RT \\
\hline Time (days) & 0 & 43 & 43 \\
\hline \multirow[t]{4}{*}{ Calculated amounts $(\mu \mathrm{g} / \mathrm{kg})$} & 45.0 & 37.8 & 43.0 \\
\hline & 35.0 & 35.8 & 41.5 \\
\hline & 48.4 & 38.6 & 42.5 \\
\hline & 36.8 & 37.6 & 40.9 \\
\hline Average amount $(\mu \mathrm{g} / \mathrm{kg})$ & 40.6 & 39.9 & 43.2 \\
\hline $\mathrm{N}$ & 6 & 6 & 6 \\
\hline st. $\operatorname{dev}(\mu \mathrm{g} / \mathrm{kg})$ & 5.97 & 4.05 & 2.06 \\
\hline
\end{tabular}




\section{Annex 5 Invitation letter}

WAGENINGEN

UNIVERSITY \& RESEARCH

RIKILT

\begin{tabular}{l|l|l} 
P.O. Box 230 & 6700 AE WAGENINGEN & The Netherlands
\end{tabular}

Manch 7, 2018

Invitastion first EUPL

mycotoxins \& plant toxins

proficiency test deoxynivalenol

and related compounds in food

and feed matrices

noukromon:

NR

our esmosis:

RUKILT/EURLPT-MPO1/2018

Dear Madam/Sir,

P.O. Box 230

6700 AE WAGENINGEN

The European Union Reference Laboratory for mycotoxins and plant toxins announces the first proficiency test on deoxynivalenol and related compounds in food and feed matrices, EURLPT-MP01.

Aim of the PT is to provide laboratories with an assessment of their analytical performance and the reliability of their data - in comparison to other laboratories.

\section{Obliged and eligible laboratories}

According to Regulation (EU) 2017/625 it is obligatory for EU National Reference Laboratories (NRLs) mycotoxins in food and/or feed to participate.

For NRLs the participation is free of charge. If an extra batch of test materials is needed after the first shipping, the courier costs will be charged.

Official laboratories (OLs) can also participate as long as sufficient test material is available, at a first come first serve basis. The participation fee for OLs is 270 EURO per participant. OLs will be contacted for payment details upon registration.

Deadline for reqistration is 1 April 2018

\section{Test materials}

The test materials will be wheat flour and corn flour. The participants will receive approximately $35 \mathrm{gram}$ of each test material.

Target analytes 


\section{Invitation letter (continued)}

Mans
March 7, 2018
Ouswornows
RHKLLT/EURLPT-MP01/2018
mak
2 of 3

This PT will focus on the quantification of deoxynivalenol (DON) as included in Commission Regulation (EC) No 1881/2006 (food) and Commission Recommendation 2006/576/EC (feed).

It furthermore will include three related compounds of deoxynivalenol: 3-acetyl deoxynivalenol (3-Ac-DON), 15-acetyl deoxynivalenol (15-Ac-DON) and

deoxynivalenol-3-glucoside (DON-3-G). EFSA recommends monitoring of these DON related compounds ${ }^{1}$.

\section{Participation}

You can participate by completing the accompanying "EURLPT-MP01 Participation form" and return it before April 1, 2018 to: eurl.mycotoxins-planttoxins@wur.nl.

\section{Shipment of test materials and deadline for submission}

The shipment of test materials is scheduled in April week 16-17, 2018. The distribution of the test materials will be announced by e-mail. If any laboratories have holidays during the shipment period, please inform us.

Results must be submitted via the electronic submission form for which each participant must register, as explained in the "EURLPT-MP01 Participation form". See calendar below for complete time schedule EURLPT-MP01.

\section{Reporting}

Laboratory proficiency will be determined through z-scores. Confidentiality of results is guaranteed. The results of the proficiency test will be presented anonymously in the report. The report will be published in the public domain of the EURL Mycotoxins \& plant toxins website. The results of this PT will be discussed during the EURL workshop.

Kind regards,

$$
\text { D. Pereloom }
$$

Diana Pereboom

Proficiency tests

EURL mycotoxins \& plant toxins RIKILT Wageningen University \& Research the Netherlands

\footnotetext{
${ }^{1} \mathrm{http}: / /$ onlinelibrary.wiley.com/doi/10.2903/.efsa.2017.4718/epdt
} 


\section{Invitation letter (continued)}

\begin{tabular}{|c|c|c|}
\hline \multicolumn{2}{|c|}{$\begin{array}{l}\text { Calendar EURLPT-MP01 } \\
\text { (last update March } 7 \text { 2018) }\end{array}$} & \multirow{3}{*}{ 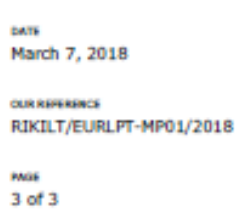 } \\
\hline Activity & Date & \\
\hline Announcement; Calendar; Target mycotoxins; & March 7, 2018 & \\
\hline \multicolumn{2}{|l|}{ Registration form } & \\
\hline Deadline for registration & April 1, 2018 & \\
\hline Distribution of test materials & April week 16-17, 2018 & \\
\hline Deadline for receipt and acceptance of test materials & within $24 \mathrm{hr}$ on receipt & \\
\hline Deadline for result submission & 6 weeks after shipment & \\
\hline $\begin{array}{l}\text { Preliminary report (only compilation of results) } \\
\text { published }\end{array}$ & August 2018 & \\
\hline Discussion on results & October $9-10,2018$ & \\
\hline Final Report published & November 2018 & \\
\hline
\end{tabular}




\section{Annex 6 Instruction letter}

WAGENINGEN

UNIVERSITY \& RESEARCH

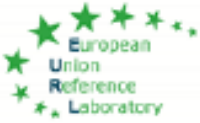

RIKILT

Apdill 23, 2018

Instruction prondency test dearyilvaienol and related compounds in food and fees matrices

Dear Madam, Sir,

arksmenc:

$1810940 / 2 I K$

(RRKILT/EURLPT-MPO1/2018)

Thank you very much for your interest in the proficiency test for the analysis of deoxynivalenol and related compounds in food and feed matrices. Hereby I send you a parcel containing two randomly coded samples. Each sample consists of approximately 35 grams of test material.

Please fill out the accompanying acknowledgement of receipt form and return it immediately upon receipt of the samples, preferably by e-mail (pt.rikilt@wur.nl)

Instructions:

- After arrival store the samples in the freezer.

- Before analysis, homogenize them according to your laboratory's procedure.

- $\quad$ Treat the test material as if it was a sample for routine analysis.

Report one result and not an average of multiple measurements.

Report all results in $\mu \mathrm{g} / \mathrm{kg}$ relative to a feed with a moisture content of $12 \%$ (assuming $0 \%$ moisture in the sample).

Please use the web application for entering your results

(https://crlwebshop,wur.nl/apex/f?p=107:LOGIN). Information about the use of this web application was sent to you earlier by e-mail.

The deadline for submitting test-results for this test is June $4^{\text {th }} 2018$.

Your username is:

Your password is:

Your lab code to enter this proficiency test is:

Please inform us about your applied method and detection technique (via the web application).

Please contact me if you have any questions or need any assistance.

With kind regards,

Diana Pereboom

Proficiency tests

EURL mycotoxins \& plant toxins

RIKILT Wageningen University \& Research, the Netherlands

P.o. Box 230

6700 AE WAGENINGEN

The Netherlands

mancos nomkes

Wageningen Camous

Bullaling 123

Abcermaalsbos 2

6708 WB WAGENINGEN

эrises:

mww.wur.nyntiat

09098104

mosesen

D.P.K.H. Pereboom - de Fauw

mencose

$+31(0) 614323017$

pt.rikite mur.nl
Wrgeringen Research

roundecion/Racalt is part of

Wegeningen Unitraratly a Rerewch. RIKAL antes ouk research into the

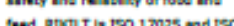

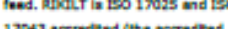

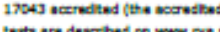

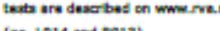




\section{Annex 7 Scope and LOQ}

\begin{tabular}{|c|c|c|c|c|}
\hline Participant code & DON & 3-Ac-DON & 15-Ac-DON & DON-3G \\
\hline & \multicolumn{4}{|c|}{ LOQ in $\mu \mathrm{g} / \mathrm{kg}$} \\
\hline РT031 & 50 & & & 50 \\
\hline PT032 & 30 & 40 & 40 & \\
\hline РT033 & 50 & & & \\
\hline РT034 & 26 & & & \\
\hline PT035 & 10 & 10 & 20 & 10 \\
\hline РT036 & 50 & 500 & 500 & 500 \\
\hline PT037 & 75 & 20 & 20 & 20 \\
\hline PT038 & 25 & 25 & 25 & \\
\hline РT039 & 50 & & & \\
\hline PT040 & 256 & & & \\
\hline PT041 & 50 & 50 & 50 & \\
\hline РT042 & 157 & & & \\
\hline PT043 & 120 & & & \\
\hline PT044 & 200 & & & \\
\hline РT045 & 100 & 100 & 100 & \\
\hline PT046 & 20 & 10 & 40 & \\
\hline РT047 & 0.195 & & & \\
\hline PT048 & 50 & & & \\
\hline PT049 & 250 & & & \\
\hline РT050 & 100 & & & \\
\hline PT051 & $?$ & & & \\
\hline PT052 & 200 & 90 & 150 & 200 \\
\hline РT053 & 13 & 16 & 20 & 2.5 \\
\hline PT054 & 20 & 20 & 20 & \\
\hline PT055 & 50 & 25 & 25 & 50 \\
\hline РT056 & 40 & & & \\
\hline PT057 & 50 & 50 & 50 & 50 \\
\hline PT058 & 10 & 10 & 10 & 10 \\
\hline РT059 & 60 & 40 & 40 & \\
\hline PT060 & 20 & & & \\
\hline PT061 & 10 & & & 150 \\
\hline РT062 & 20 & & & \\
\hline PT063 & 30 & 30 & 30 & 30 \\
\hline PT064 & 200 & 200 & 200 & 200 \\
\hline РT065 & 10 & 10 & 10 & 50 \\
\hline PT066 & 203 & & & \\
\hline РT067 & 144 & & & \\
\hline PT068 & 2.5 & 2.1 & 1.8 & 1.2 \\
\hline PT069 & 150 & & & \\
\hline PT070 & 100 & & & \\
\hline PT071 & 100 & & & \\
\hline PT072 & 200 & & & \\
\hline PT073 & 80 & 80 & 80 & 200 \\
\hline PT074 & 100 & & & \\
\hline РT075 & 4 & 4 & 4 & \\
\hline РТ076 & 13.2 & 5.32 & 25 & 1.3 \\
\hline РT077 & 180 & & & \\
\hline PT9958 & 50 & & & \\
\hline PT9959 & 40 & & & \\
\hline PT9960 & 120 & & & \\
\hline
\end{tabular}




\section{Annex 8 Method details}

\begin{tabular}{|c|c|c|c|c|c|c|c|}
\hline $\begin{array}{l}\text { Participant } \\
\text { code }\end{array}$ & $\begin{array}{c}\text { Sample weight } \\
\text { (g) }\end{array}$ & Extraction solvent & $\begin{array}{l}\text { Extr. solvent } \\
\text { volume ml }\end{array}$ & $\begin{array}{l}\text { Extraction } \\
\text { conditions }\end{array}$ & Clean-up & ISTD & Measurement \\
\hline РT031 & 25 & water (5 g PEG800) & 200 & shake $30 \mathrm{~min}$ & IAC & & LC-UV \\
\hline РT032 & & ACN/water (84/16) & & & SPE (mycosep 225) & yes & LC-MS/MS \\
\hline РT033 & & $\mathrm{MeOH} /$ water & & & IAC & none & LC-MS/MS \\
\hline РT034 & & ACN/water $(70 / 30)$ & & shake $60 \mathrm{~min}$ & dilution & none & LC-MS/MS \\
\hline РT035 & 5 & ACN/water $(84 / 16)$ & 20 & shake $120 \mathrm{~min}$ & SPE (OASIS prime HLB) & & LC-MS/MS \\
\hline РT036 & & QuEChERS & & & salt-out phase partitioning & none & LC-MS/MS \\
\hline \multicolumn{8}{|l|}{ PT037 } \\
\hline PT038 & 20 & ACN/water (84/16) & & & SPE (mycosep 227) & 19-nortestosterone & GC-MS (SIM) after silylation \\
\hline РT039 & & Water & & ultraturrax & IAC & & LC-UV \\
\hline PT040 & & Water & & & IAC & & LC-UV \\
\hline PT041 & & ACN/water/HAc (79/20/1) & & & none & $13 \mathrm{C} 15-\mathrm{DON}$, not for Ac-DONs & LC-MS/MS \\
\hline PT042 & & & & & IAC & none & LC-UV \\
\hline PT043 & 5 & Water & 200 & blend $3 \mathrm{~min}$ & IAC & none & LC-UV \\
\hline РT044 & 12.5 & $\mathrm{MeOH} /$ water $(70 / 30)$ & 70 & blend $2 \mathrm{~min}$ & IAC (DZT) & none & LC-MS/MS \\
\hline \multicolumn{8}{|l|}{ РT045 } \\
\hline РT046 & & ACN/water $(84 / 16)$ & & & SPE (mycosep 225) & 13C15-DON & LC-MS/MS \\
\hline \multicolumn{8}{|l|}{ РT047 } \\
\hline PT048 & & Water & & & IAC & none & LC-UV \\
\hline PT049 & & Water & & & IAC & & LC-UV \\
\hline PT050 & 10 & $\mathrm{ACN} /$ water/HAc $(80 / 20 / 1)$ & & stir $60 \mathrm{~min}$ & & $13 \mathrm{C} 15-\mathrm{DON}$ & LC-MS/MS \\
\hline \multicolumn{8}{|l|}{ PT051 } \\
\hline PT052 & & ACN/water & & & dilution & $13 \mathrm{C}$ label for each toxin & LC-MS/MS \\
\hline РT053 & & ACN/water/HAC (79/20/1) & & $90 \mathrm{~min}$ & dilution & none & LC-MS/MS \\
\hline PT054 & & ACN/water & & & SPE & & LC-MS/MS \\
\hline PT055 & & QUEChERS & & & salt-out phase partitioning & none & LC-MS/MS \\
\hline PT056 & & Water & & shaker $60 \mathrm{~min}$ & IAC (DONprep) & & LC-UV \\
\hline PT057 & & QuEChERS (ACN/water) & & & salt-out phase partitioning & & LC-MS/MS \\
\hline
\end{tabular}




\begin{tabular}{|c|c|c|c|c|c|c|c|}
\hline $\begin{array}{l}\text { Participant } \\
\text { code }\end{array}$ & $\begin{array}{l}\text { Sample weight } \\
\text { (g) }\end{array}$ & Extraction solvent & $\begin{array}{l}\text { Extr. solvent } \\
\text { volume } \mathrm{ml}\end{array}$ & $\begin{array}{l}\text { Extraction } \\
\text { conditions }\end{array}$ & Clean-up & ISTD & Measurement \\
\hline \multicolumn{8}{|l|}{ PT058 } \\
\hline РТ059 & 5 & ACN/water/FA (79/20/1) & 25 & $60 \mathrm{~min}$ & solvent switch & 13C-labeled & LC-MS/MS \\
\hline РТ060 & & water with PEG & & & IAC & none & LC-UV \\
\hline РT061 & 2 & $\begin{array}{l}\text { QuEChERS (ACN-1\%FA/water/ } \\
(1: 1))\end{array}$ & 20 & shake $30 \mathrm{~min}$ & salt-out phase partitioning & 13C15-DON & LC-MS/MS \\
\hline РT062 & & $\mathrm{MeOH} /$ water & & shaker & IAC (DZT) & none & LC-MS/MS \\
\hline PT063 & & Water & & & IAC & none & LC-UV \\
\hline PT064 & & & & & IAC & none & LC-MS/MS \\
\hline PT065 & & EtOAC/water-1\% HAc (2:1) & & & & $13 \mathrm{C} 15-\mathrm{DON}$ & LC-MS/MS \\
\hline PT066 & & ACN/water & & & SPE (Oasis HLB) & 13C15-DON & LC-MS/MS \\
\hline PT067 & & Water & & & IAC & none & LC-UV \\
\hline РT068 & & ACN/water/FA (79/20/1) & & & & none & LC-MS/MS \\
\hline РТ069 & & Water & & & IAC & & LC-UV \\
\hline РT070 & & Water & & & IAC & & LC-UV \\
\hline PT071 & 10 & ACN/water/FA (74/52/1) & 50 & & dilution & none & LC-MS/MS \\
\hline РT072 & & & & & SPE & $13 \mathrm{C}$ & LC-MS/MS \\
\hline РT073 & 25 & ACN/water/HAc $(79 / 20 / 1)$ & 100 & stir $120 \mathrm{~min}$ & dilution & $13 \mathrm{C}$ label for each toxin & LC-MS/MS \\
\hline РT074 & & Water & & & IAC & none & LC-UV \\
\hline PT075 & 5 & $\mathrm{ACN} /$ water; $\mathrm{ACN}$ & $20 ; 20$ & shake $30 \mathrm{~min}$ & SPE (mycosep afla/zon) & 13C15-DON & LC-MS/MS \\
\hline РT076 & 1 & ACN/water $(84 / 16)$ & 8 & & SPE (mycosep Trich 225) & $13 C 15 \mathrm{DON}$ and $13 \mathrm{C} 21 \mathrm{DON} 3-\mathrm{G}$ & LC-MS/MS \\
\hline РT077 & & QuEChERS (modified) & & & salt-out phase partitioning & $13 \mathrm{C}$ label for each toxin & LC-MS/MS \\
\hline PT9958 & 5 & QuEChERS (ACN-1\% FA/water) & $10 ; 10$ & shake $1 \mathrm{~min}$ & salt-out phase partitioning & 13C15-DON & LC-MS/MS \\
\hline \multicolumn{8}{|l|}{ PT9959 } \\
\hline PT9960 & & Water & & & IAC (DONprep) & & LC-UV \\
\hline
\end{tabular}

$\mathrm{ACN}=$ acetonitrile; $\mathrm{EtOAC}=$ ethyl acetate; $\mathrm{FA}=$ formic acid; $\mathrm{HAC}=$ acetic acid; $\mathrm{MeOH}=$ methanol; PEG = polyethylene glycol (PEG)

$\mathrm{SPE}=$ solid phase extraction; $\mathrm{IAC}=$ immunoaffinity column 


\section{Annex 9 Results material A (wheat)}

\begin{tabular}{|c|c|c|c|c|}
\hline \multirow{8}{*}{$\begin{array}{l}\text { Part. } \\
\text { code }\end{array}$} & \multicolumn{2}{|c|}{ Material A } & \multicolumn{2}{|c|}{ Material A } \\
\hline & \multicolumn{2}{|c|}{ DON } & \multicolumn{2}{|c|}{ 3-Ac-DON } \\
\hline & \multicolumn{2}{|c|}{ C: $572 \mu \mathrm{g} / \mathrm{kg}$} & \multicolumn{2}{|c|}{ C: $34.5 \mu \mathrm{g} / \mathrm{kg}$} \\
\hline & \multicolumn{2}{|c|}{ u: $15.5 \mu \mathrm{g} / \mathrm{kg}$} & \multicolumn{2}{|c|}{$\mathrm{u}: 2.16 \mu \mathrm{g} / \mathrm{kg}$} \\
\hline & \multicolumn{2}{|c|}{$\sigma_{p}: 143 \mu g / k g(25 \%)$} & \multicolumn{2}{|c|}{$\sigma_{p}: 8.62 \mu g / k g(25 \%)$} \\
\hline & \multicolumn{2}{|c|}{ robust o: $86.5 \mu \mathrm{g} / \mathrm{kg}(15 \%)$} & \multicolumn{2}{|c|}{ robust o: $7.32 \mu \mathrm{g} / \mathrm{kg}(21 \%)$} \\
\hline & Result & z-score & Result & z-score \\
\hline & $(\mu g / k g)$ & & $(\mu \mathrm{g} / \mathrm{kg})$ & \\
\hline PT031 & 556.03 & -0.1 & & \\
\hline РT032 & 770 & 1.4 & 133 & 11 \\
\hline РТ033 & 113 & -3.2 & & \\
\hline PT034 & 606 & 0.2 & & \\
\hline РT035 & 452 & -0.8 & 33.1 & -0.2 \\
\hline РТ036 & 572.3 & 0.0 & $<500$ & $(54)$ \\
\hline РT037 & 792 & 1.5 & 33 & -0.2 \\
\hline РT038 & 542.9 & -0.2 & 27.6 & -0.8 \\
\hline РТ039 & 574.6 & 0.0 & & \\
\hline РT040 & 745 & 1.2 & & \\
\hline РT041 & 672.5 & 0.7 & 42.2 & 0.9 \\
\hline PT042 & 835 & 1.8 & & \\
\hline PT043 & 667 & 0.7 & & \\
\hline РT044 & 508 & -0.5 & & \\
\hline PT045 & 643 & 0.5 & 66.9 & 3.8 \\
\hline РT046 & 497 & -0.5 & 34.3 & -0.0 \\
\hline РT047 & 685.464 & 0.8 & & \\
\hline PT048 & 600.3 & 0.2 & & \\
\hline РT049 & 528 & -0.3 & & \\
\hline PT050 & 760 & 1.3 & & \\
\hline PT051 & 670 & 0.7 & & \\
\hline РT052 & 555 & -0.1 & $<90$ & (6) \\
\hline PT053 & 527 & -0.3 & 42.2 & 0.9 \\
\hline PT054 & 440 & -0.9 & 21 & -1.6 \\
\hline PT055 & 488.1 & -0.6 & 31.5 & -0.3 \\
\hline
\end{tabular}

$C=$ consensus value (robust mean)

$\mathrm{u}=$ uncertainty of consensus value

$\sigma_{\mathrm{p}}=$ target standard deviation for proficiency

robust $\sigma=$ robust (relative) standard deviation based on participants' results 


\begin{tabular}{|c|c|c|c|c|}
\hline \multirow{8}{*}{$\begin{array}{l}\text { Part. } \\
\text { code }\end{array}$} & \multicolumn{2}{|c|}{ Material A } & \multicolumn{2}{|c|}{ Material A } \\
\hline & \multicolumn{2}{|c|}{ DON } & \multicolumn{2}{|c|}{ 3-AC-DON } \\
\hline & \multicolumn{2}{|c|}{ 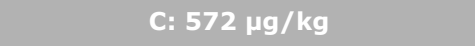 } & \multicolumn{2}{|c|}{ C: $34.5 \mu g / k g$} \\
\hline & \multicolumn{2}{|c|}{ u: $15.5 \mu g / k g$} & \multicolumn{2}{|c|}{ u: $2.16 \mu g / k g$} \\
\hline & \multicolumn{2}{|c|}{$\sigma_{p}: 143 \mu g / k g(25 \%)$} & \multicolumn{2}{|c|}{$\sigma_{\mathrm{p}}: 8.62 \mu \mathrm{g} / \mathrm{kg}(25 \%)$} \\
\hline & \multicolumn{2}{|c|}{ robust o: $86.5 \mu \mathrm{g} / \mathrm{kg}(15 \%)$} & \multicolumn{2}{|c|}{ robust $\sigma: 7.32 \mu \mathrm{g} / \mathrm{kg}(21 \%)$} \\
\hline & Result & z-score & Result & z-score \\
\hline & $(\mu g / \mathrm{kg})$ & & $(\mu g / \mathrm{kg})$ & \\
\hline РT056 & 543.6 & -0.2 & & \\
\hline РT057 & 552 & -0.1 & 96 & 7.1 \\
\hline РT058 & 610 & 0.3 & 35 & 0.1 \\
\hline РT059 & 560 & -0.1 & $<40$ & $(0.6)$ \\
\hline РT060 & 600 & 0.2 & & \\
\hline РT061 & 556.3 & -0.1 & & \\
\hline PT062 & 510 & -0.4 & & \\
\hline РT063 & 533 & -0.3 & 88 & 6.2 \\
\hline РT064 & 842 & 1.9 & 28.8 & -0.7 \\
\hline PT065 & 609 & 0.3 & 34 & -0.1 \\
\hline РT066 & 446.3 & -0.9 & & \\
\hline РT067 & 569 & -0.0 & & \\
\hline РT068 & 621 & 0.3 & 37.6 & 0.4 \\
\hline PT069 & 503 & -0.5 & & \\
\hline РТ070 & 529 & -0.3 & & \\
\hline PT071 & 560 & -0.1 & & \\
\hline РT072 & 564 & -0.1 & & \\
\hline РT073 & 466 & -0.7 & 31 & -0.4 \\
\hline РT074 & 582.5 & 0.1 & & \\
\hline РT075 & 491.9 & -0.6 & 20.7 & -1.6 \\
\hline РT076 & 502 & -0.5 & 32 & -0.3 \\
\hline РТ077 & 563 & -0.1 & & \\
\hline PT9958 & 600 & 0.2 & & \\
\hline PT9959 & 452 & -0.8 & & \\
\hline РТ9960 & 1004 & 3.0 & & \\
\hline
\end{tabular}

$\mathrm{C}=$ consensus value (robust mean)

$\mathrm{u}=$ uncertainty of consensus value

$\sigma_{\mathrm{p}}=$ target standard deviation for proficiency

robust $\sigma=$ robust (relative) standard deviation based on participants' results 


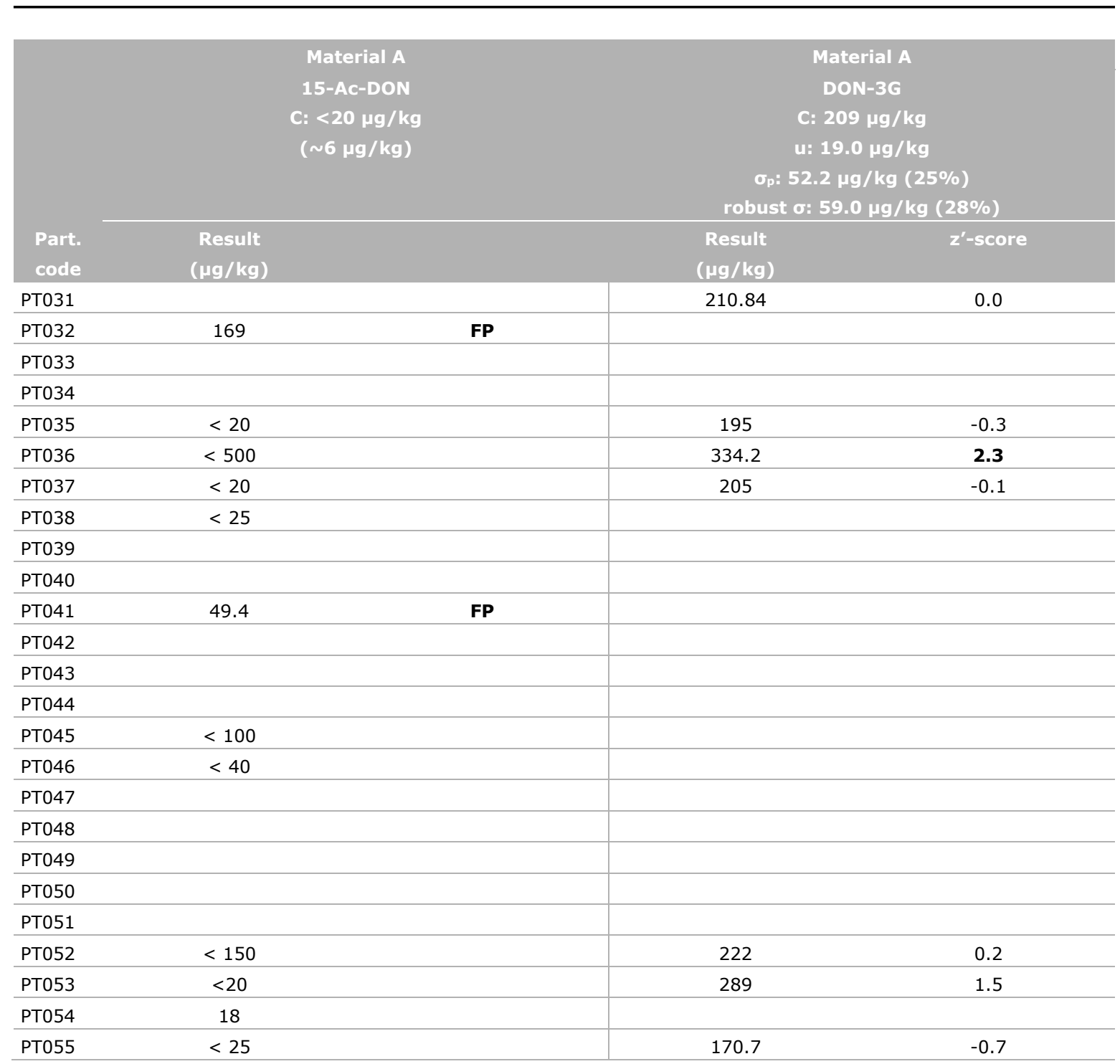

$\mathrm{C}=$ consensus value (robust mean)

$\mathrm{u}=$ uncertainty of consensus value

$\sigma_{\mathrm{p}}=$ target standard deviation for proficiency

robust $\sigma=$ robust (relative) standard deviation based on participants' results 


\begin{tabular}{|c|c|c|c|c|}
\hline \multirow[b]{2}{*}{$\begin{array}{l}\text { Part. } \\
\text { code }\end{array}$} & \multicolumn{2}{|c|}{$\begin{array}{c}\text { Material A } \\
\text { 15-AC-DON } \\
\text { C: }<20 \mu \mathrm{g} / \mathrm{kg} \\
(\sim 6 \mu \mathrm{g} / \mathrm{kg})\end{array}$} & \multicolumn{2}{|c|}{$\begin{array}{c}\text { Material A } \\
\text { DON-3G } \\
\text { C: } 209 \mu \mathrm{g} / \mathrm{kg} \\
\text { u: } 19.03 \mu \mathrm{gg} / \mathrm{kg} \\
\text { op: } 52.2 \mu \mathrm{gg}(25 \%) \\
\text { robust o: } 59.0 \mu \mathrm{kg} / \mathrm{kg}(28 \%)\end{array}$} \\
\hline & \multicolumn{2}{|l|}{$\begin{array}{c}\text { Result } \\
(\mu \mathrm{g} / \mathrm{kg})\end{array}$} & $\begin{array}{l}\text { Result } \\
\text { ( } \mu \mathrm{g} / \mathrm{kg})\end{array}$ & $z^{\prime}$-score \\
\hline \multicolumn{5}{|l|}{ РT056 } \\
\hline РT057 & $<50$ & & 320 & 2.0 \\
\hline PT058 & $<10$ & & 160 & -0.9 \\
\hline PT059 & $<40$ & & & \\
\hline \multicolumn{5}{|l|}{ РT060 } \\
\hline РT061 & & & 292.9 & 1.5 \\
\hline \multicolumn{5}{|l|}{ PT062 } \\
\hline PT063 & 290 & $\mathbf{F P}$ & 128 & -1.5 \\
\hline РT064 & 28.6 & (FP?) & 436 & 4.1 \\
\hline РT065 & 11 & & 103 & -1.9 \\
\hline \multicolumn{5}{|l|}{ РT066 } \\
\hline \multicolumn{5}{|l|}{ РT067 } \\
\hline PT068 & 7.1 & & 181 & -0.5 \\
\hline \multicolumn{5}{|l|}{ PT069 } \\
\hline \multicolumn{5}{|l|}{ РT070 } \\
\hline \multicolumn{5}{|l|}{ РT071 } \\
\hline \multicolumn{5}{|l|}{ РT072 } \\
\hline РT073 & 11 & & 193 & -0.3 \\
\hline \multicolumn{5}{|l|}{ РT074 } \\
\hline РT075 & 6.9 & & & \\
\hline РT076 & $<25$ & & 215 & 0.11 \\
\hline \multicolumn{5}{|l|}{ РT077 } \\
\hline \multicolumn{5}{|l|}{ PT9958 } \\
\hline \multicolumn{5}{|l|}{ PT9959 } \\
\hline РT9960 & & & & \\
\hline
\end{tabular}

$\mathrm{C}=$ consensus value (robust mean)

$\mathrm{u}=$ uncertainty of consensus value

$\sigma_{\mathrm{p}}=$ target standard deviation for proficiency

robust $\sigma=$ robust (relative) standard deviation based on participants' results 


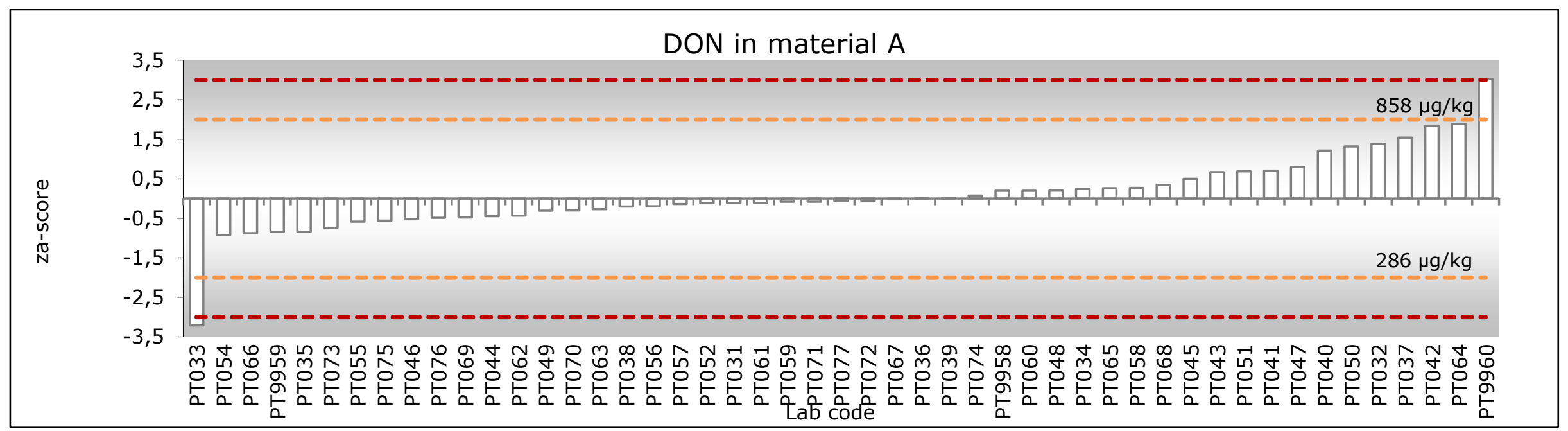

Figure a Graphical representation of the $z$-scores for DON in material A (wheat). Dotted lines show PT performance boundaries \pm 2 (also in $\mu g / k g)$ and \pm 3 .

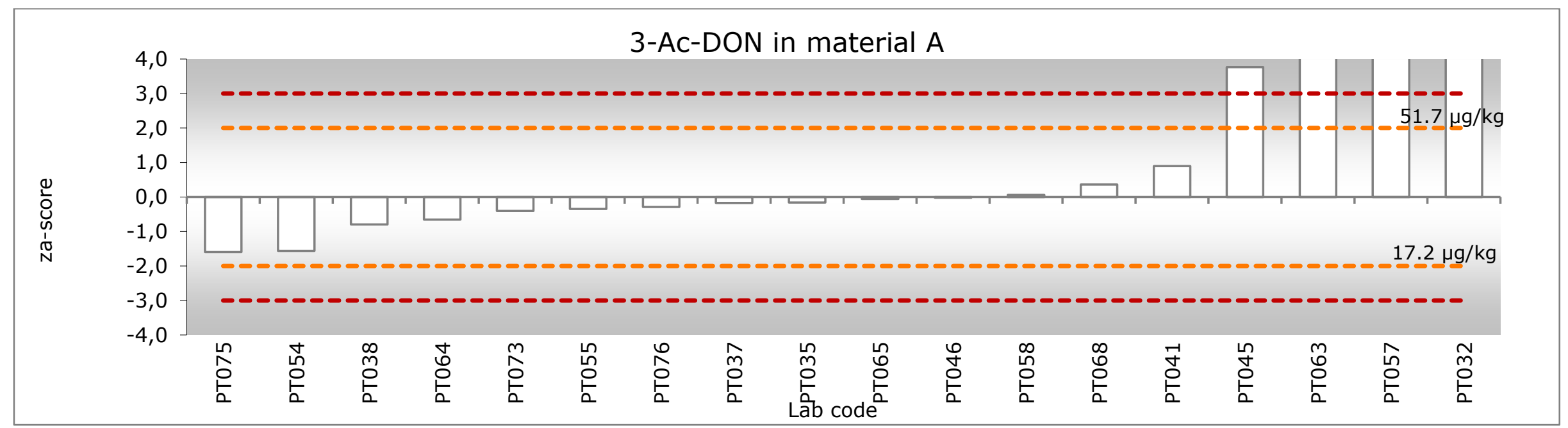

Figure $\boldsymbol{b} \quad$ Graphical representation of the $z$-scores for 3-Ac-DON in material A. Dotted lines show PT performance boundaries \pm 2 (also in $\mu \mathrm{g} / \mathrm{kg}$ ) and \pm 3. 


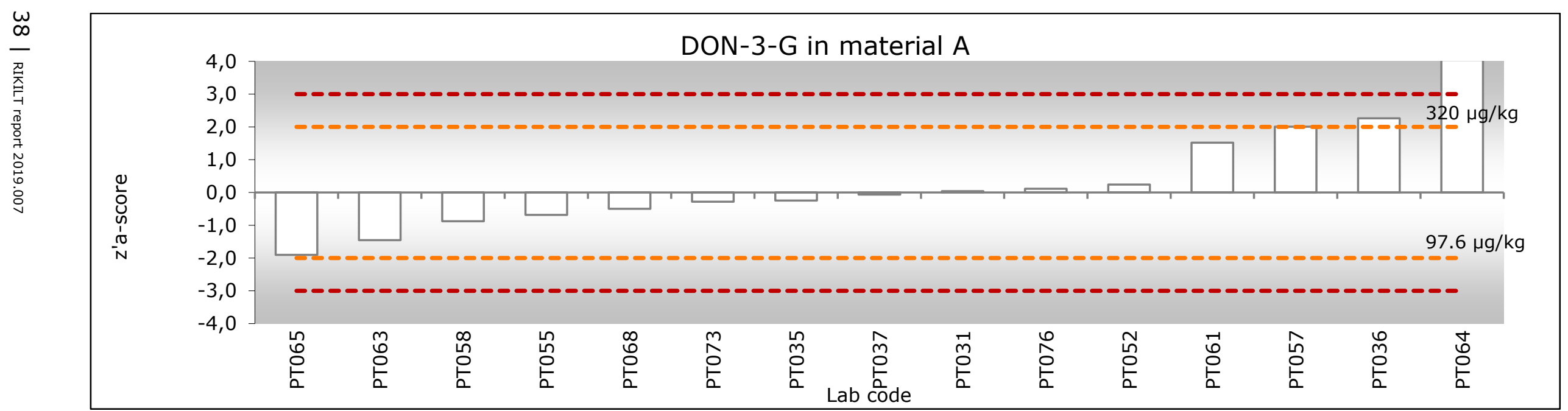

Figure c Graphical representation of the $z^{\prime}-$ scores for DON-3G in material B. Dotted lines show PT performance boundaries \pm 2 (also in $\left.\mu g / k g\right)$ and \pm 3 . 


\section{Annex 10 Results material B}

\begin{tabular}{|c|c|c|c|c|}
\hline \multirow{8}{*}{$\begin{array}{l}\text { Part. } \\
\text { code }\end{array}$} & \multicolumn{2}{|c|}{ Material B } & \multicolumn{2}{|c|}{ Material B } \\
\hline & \multicolumn{2}{|c|}{ DON } & \multicolumn{2}{|c|}{ 3-AC-DON } \\
\hline & \multicolumn{2}{|c|}{ 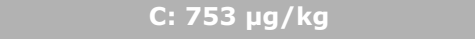 } & \multicolumn{2}{|c|}{ C: $93.4 \mu \mathrm{g} / \mathrm{kg}$} \\
\hline & \multicolumn{2}{|c|}{ u: $21.5 \mu g / k g$} & \multicolumn{2}{|c|}{ u: $4.53 \mathrm{\mu g} / \mathrm{kg}$} \\
\hline & \multicolumn{2}{|c|}{$\sigma_{p}: 188 \mu g / k g(25 \%)$} & \multicolumn{2}{|c|}{$\sigma_{\mathrm{p}}: 23.3 \mu \mathrm{g} / \mathrm{kg}(25 \%)$} \\
\hline & \multicolumn{2}{|c|}{ robust o: $120 \mu g / k g(16 \%)$} & \multicolumn{2}{|c|}{ robust o: $16.6 \mu g / \mathrm{kg}(18 \%)$} \\
\hline & Result & z-score & Result & z-score \\
\hline & $(\mu g / \mathrm{kg})$ & & $(\mu g / k g)$ & \\
\hline PT031 & 759.19 & 0.0 & & \\
\hline РT032 & 549 & -1.1 & 74 & -0.8 \\
\hline РT033 & 144 & -3.2 & & \\
\hline РT034 & 742 & -0.1 & & \\
\hline PT035 & 636 & -0.6 & 105 & 0.5 \\
\hline PT036 & 937.4 & 1.0 & 117.2 & 1.0 \\
\hline PT037 & 770 & 0.1 & 129 & 1.5 \\
\hline PT038 & 809.1 & 0.3 & 68.7 & -1.1 \\
\hline PT039 & 719.8 & -0.2 & & \\
\hline РT040 & 1018 & 1.4 & & \\
\hline РT041 & 826.5 & 0.4 & 106.8 & 0.6 \\
\hline РT042 & 1100 & 1.8 & & \\
\hline PT043 & 766 & 0.1 & & \\
\hline PT044 & 554 & -1.1 & & \\
\hline PT045 & 561 & -1.0 & 88.3 & -0.2 \\
\hline PT046 & 683 & -0.4 & 83.6 & -0.4 \\
\hline PT047 & 926.431 & 0.9 & & \\
\hline PT048 & 811.2 & 0.3 & & \\
\hline РT049 & 685 & -0.4 & & \\
\hline РT050 & 1060 & 1.6 & & \\
\hline PT051 & 777 & 0.1 & & \\
\hline PT052 & 753 & 0.0 & 95 & 0.1 \\
\hline PT053 & 688 & -0.3 & 90.4 & -0.1 \\
\hline PT054 & 616 & -0.7 & 55 & -1.6 \\
\hline PT055 & 616.1 & -0.7 & 94.7 & 0.1 \\
\hline
\end{tabular}

$C=$ consensus value (robust mean)

$\mathrm{u}=$ uncertainty of consensus value

$\sigma_{p}=$ target standard deviation for proficiency

robust $\sigma=$ robust (relative) standard deviation based on participants' results 


\begin{tabular}{|c|c|c|c|c|}
\hline \multirow{8}{*}{$\begin{array}{l}\text { Lab } \\
\text { code }\end{array}$} & \multicolumn{2}{|c|}{ Material B } & \multicolumn{2}{|c|}{ Material B } \\
\hline & \multicolumn{2}{|c|}{ DON } & \multicolumn{2}{|c|}{ 3-AC-DON } \\
\hline & \multicolumn{2}{|c|}{ 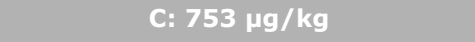 } & \multicolumn{2}{|c|}{ C: $93.4 \mu \mathrm{g} / \mathrm{kg}$} \\
\hline & \multicolumn{2}{|c|}{ u: $21.5 \mu g / k g$} & \multicolumn{2}{|c|}{ u: $4.53 \mu g / k g$} \\
\hline & \multicolumn{2}{|c|}{$\sigma_{p}: 188 \mu g / k g(25 \%)$} & \multirow{2}{*}{\multicolumn{2}{|c|}{$\begin{array}{c}\sigma_{\mathrm{p}}: 23.3 \mu \mathrm{g} / \mathrm{kg}(25 \%) \\
\text { robust } \sigma: 16.6 \mu \mathrm{gg} / \mathrm{kg}(18 \%)\end{array}$}} \\
\hline & \multicolumn{2}{|c|}{ robust o: 120 jg/kg (16\%) } & & \\
\hline & Result & z-score & Result & z-score \\
\hline & $(\mu g / \mathrm{kg})$ & & $(\mu \mathrm{g} / \mathrm{kg})$ & \\
\hline PT056 & 930.9 & 0.9 & & \\
\hline PT057 & 745 & -0.0 & 219 & 5.4 \\
\hline PT058 & 770 & 0.1 & 85 & -0.4 \\
\hline РT059 & 700 & -0.3 & 89 & -0.2 \\
\hline PT060 & 715 & -0.2 & & \\
\hline PT061 & 939.1 & 1.0 & & \\
\hline PT062 & 670 & -0.4 & & \\
\hline PT063 & 605 & -0.8 & 70 & -1.0 \\
\hline PT064 & 838 & 0.5 & 93.9 & 0.0 \\
\hline PT065 & 1012 & 1.4 & 108 & 0.6 \\
\hline РT066 & 637.3 & -0.6 & & \\
\hline PT067 & 800 & 0.3 & & \\
\hline PT068 & 746 & -0.0 & 95.5 & 0.1 \\
\hline PT069 & 680 & -0.4 & & \\
\hline PT070 & 744 & -0.1 & & \\
\hline РT071 & 850 & 0.5 & & \\
\hline РТ072 & 713 & -0.2 & & \\
\hline РТ073 & 682 & -0.4 & 100 & 0.3 \\
\hline PT074 & 776.3 & 0.1 & & \\
\hline PT075 & 741 & -0.1 & 88.4 & -0.2 \\
\hline PT076 & 729 & -0.1 & 90.2 & -0.1 \\
\hline РT077 & 879 & 0.7 & & \\
\hline PT9958 & 820 & 0.4 & & \\
\hline РT9959 & 568 & -1.0 & & \\
\hline РT9960 & 1064 & 1.7 & & \\
\hline
\end{tabular}

$C=$ consensus value (robust mean)

$\mathrm{u}=$ uncertainty of consensus value

$\sigma_{p}=$ target standard deviation for proficiency

robust $\sigma=$ robust (relative) standard deviation based on participants' results 


\begin{tabular}{|c|c|c|c|c|}
\hline \multirow{8}{*}{$\begin{array}{l}\text { Part. } \\
\text { code }\end{array}$} & \multicolumn{2}{|c|}{ Material B } & \multicolumn{2}{|c|}{ Material B } \\
\hline & \multicolumn{2}{|c|}{ 15-AC-DON } & \multicolumn{2}{|c|}{ DON-3G } \\
\hline & \multicolumn{2}{|c|}{ 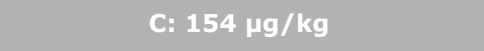 } & \multicolumn{2}{|c|}{ C: $35.1 \mu \mathrm{g} / \mathrm{kg}$} \\
\hline & \multicolumn{2}{|c|}{ u: $11.6 \mu \mathrm{g} / \mathrm{kg}$} & \multicolumn{2}{|c|}{ u: $1.91 \mu \mathrm{g} / \mathrm{kg}$} \\
\hline & \multicolumn{2}{|c|}{$\sigma_{p}: 38.6 \mu g / k g(25 \%)$} & \multirow{2}{*}{\multicolumn{2}{|c|}{$\begin{array}{c}\sigma_{\mathrm{p}}: 8.77 \mu \mathrm{g} / \mathrm{kg}(25 \%) \\
\text { robust } \sigma: 4.83 \mu \mathrm{gg} / \mathrm{kg}(14 \%)\end{array}$}} \\
\hline & \multicolumn{2}{|c|}{ robust o: $40.4 \mu \mathrm{g} / \mathrm{kg}(26 \%)$} & & \\
\hline & Result & $z^{\prime}$-score & \multirow{2}{*}{\multicolumn{2}{|c|}{$\begin{array}{c}\text { Result } \\
(\mu \mathrm{g} / \mathrm{kg})\end{array}$}} \\
\hline & $(\mu g / \mathrm{kg})$ & & & \\
\hline РT031 & & & 34.63 & -0.1 \\
\hline РT032 & $<40$ & $(-3.0) \mathbf{F N}$ & & \\
\hline \multicolumn{5}{|l|}{ РT033 } \\
\hline \multicolumn{5}{|l|}{ РT034 } \\
\hline РT035 & 153 & -0.0 & 33.1 & -0.2 \\
\hline РT036 & 147.3 & -0.2 & $<500$ & $(53)$ \\
\hline PT037 & 208 & 1.3 & 34 & -0.1 \\
\hline РT038 & 137.2 & -0.4 & & \\
\hline \multicolumn{5}{|l|}{ РT039 } \\
\hline \multicolumn{5}{|l|}{ РT040 } \\
\hline РT041 & 128 & -0.7 & & \\
\hline \multicolumn{5}{|l|}{ РT042 } \\
\hline \multicolumn{5}{|l|}{ PT043 } \\
\hline \multicolumn{5}{|l|}{ РT044 } \\
\hline РT045 & 91.5 & -1.6 & & \\
\hline PT046 & 106 & -1.2 & & \\
\hline \multicolumn{5}{|l|}{ РT047 } \\
\hline \multicolumn{5}{|l|}{ РT048 } \\
\hline \multicolumn{5}{|l|}{ РT049 } \\
\hline \multicolumn{5}{|l|}{ РT050 } \\
\hline \multicolumn{5}{|l|}{ РT051 } \\
\hline РT052 & 167 & 0.3 & $<200$ & (19) \\
\hline PT053 & 113 & -1.1 & 34.7 & -0.0 \\
\hline PT054 & 229 & 1.9 & & \\
\hline РТ055 & 155 & 0.0 & $<50$ & $(1.7)$ \\
\hline
\end{tabular}

$\mathrm{C}=$ consensus value (robust mean)

$\mathrm{u}=$ uncertainty of consensus value

$\sigma_{\mathrm{p}}=$ target standard deviation for proficiency

robust $\sigma=$ robust (relative) standard deviation based on participants' results 


\begin{tabular}{|c|c|c|c|c|}
\hline \multirow{8}{*}{$\begin{array}{l}\text { Part. } \\
\text { code }\end{array}$} & \multicolumn{2}{|c|}{ Material B } & \multicolumn{2}{|c|}{ Material B } \\
\hline & \multicolumn{2}{|c|}{ 15-Ac-DON } & \multicolumn{2}{|c|}{ DON-3G } \\
\hline & \multicolumn{2}{|c|}{ C: $154 \mu \mathrm{g} / \mathrm{kg}$} & \multicolumn{2}{|c|}{ C: $35.1 \mu g / k g$} \\
\hline & \multicolumn{2}{|c|}{ u: $11.6 \mu \mathrm{g} / \mathrm{kg}$} & \multicolumn{2}{|c|}{ u: $1.91 \mu g / k g$} \\
\hline & \multicolumn{2}{|c|}{$\sigma_{p}: 38.6 \mu \mathrm{g} / \mathrm{kg}(25 \%)$} & \multicolumn{2}{|c|}{$\sigma_{p}: 8.77 \mu g / k g(25 \%)$} \\
\hline & \multicolumn{2}{|c|}{ robust o: $40.4 \mathrm{\mu g} / \mathrm{kg}(26 \%)$} & \multicolumn{2}{|c|}{ robust $\sigma: 4.83 \mu \mathrm{g} / \mathrm{kg}(14 \%)$} \\
\hline & Result & $z^{\prime}$-score & Result & z-score \\
\hline & $(\mu \mathrm{g} / \mathrm{kg})$ & & $(\mu \mathrm{g} / \mathrm{kg})$ & \\
\hline \multicolumn{5}{|l|}{ PT056 } \\
\hline PT057 & 287 & 3.3 & 30 & -0.6 \\
\hline PT058 & 130 & -0.6 & 25 & -1.2 \\
\hline PT059 & 115 & -1.0 & & \\
\hline \multicolumn{5}{|l|}{ РT060 } \\
\hline РT061 & & & $<150$ & (13) \\
\hline \multicolumn{5}{|l|}{ PT062 } \\
\hline PT063 & $<30$ & $(-3.2) \mathbf{F N}$ & 37 & 0.2 \\
\hline РT064 & 95.1 & -1.5 & 76.6 & 4.7 \\
\hline PT065 & 170 & 0.4 & $<50$ & $(1.7)$ \\
\hline \multicolumn{5}{|l|}{ РT066 } \\
\hline \multicolumn{5}{|l|}{ РT067 } \\
\hline РT068 & 183 & 0.7 & 34.4 & -0.1 \\
\hline \multicolumn{5}{|l|}{ PT069 } \\
\hline \multicolumn{5}{|l|}{ РT070 } \\
\hline \multicolumn{5}{|l|}{ PT071 } \\
\hline \multicolumn{5}{|l|}{ PT072 } \\
\hline РT073 & 173 & 0.5 & 38 & 0.3 \\
\hline \multicolumn{5}{|l|}{ РT074 } \\
\hline PT075 & 179.2 & 0.6 & & \\
\hline РT076 & 159 & 0.1 & 47.5 & 1.4 \\
\hline \multicolumn{5}{|l|}{ РT077 } \\
\hline \multicolumn{5}{|l|}{ PT9958 } \\
\hline \multicolumn{5}{|l|}{ PT9959 } \\
\hline PT9960 & & & & \\
\hline
\end{tabular}

$\mathrm{C}=$ consensus value (robust mean)

$\mathrm{u}=$ uncertainty of consensus value

$\sigma_{\mathrm{p}}=$ target standard deviation for proficiency

robust $\sigma=$ robust (relative) standard deviation based on participants' results 


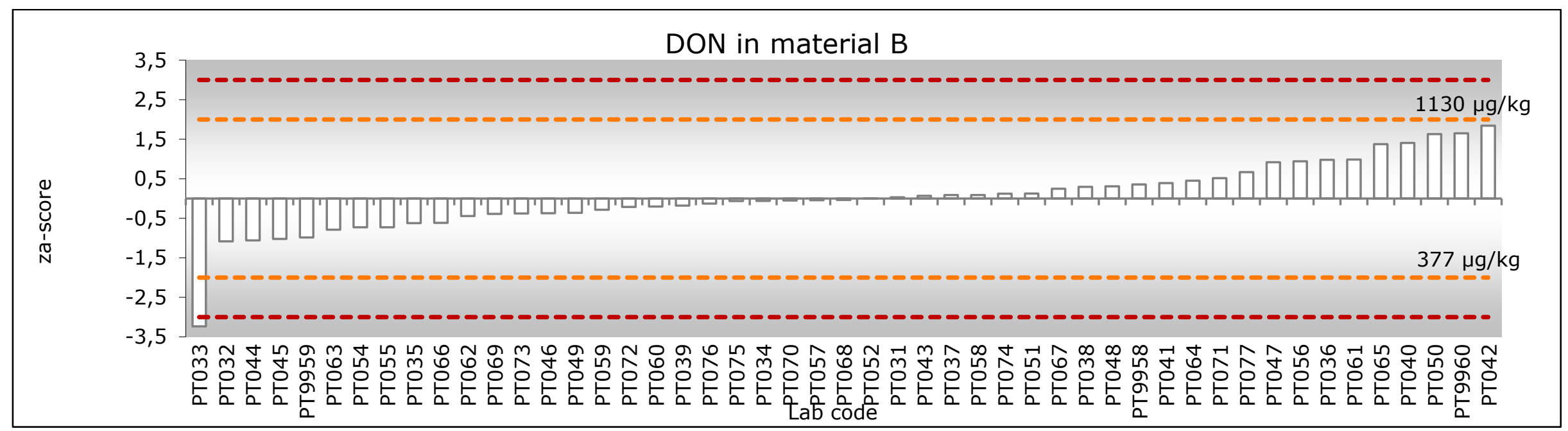

Figure d Graphical representation of the z-scores for DON in material B. Dotted lines show PT performance boundaries \pm 2 (also in $\mu g / k g$ ) and \pm 3.

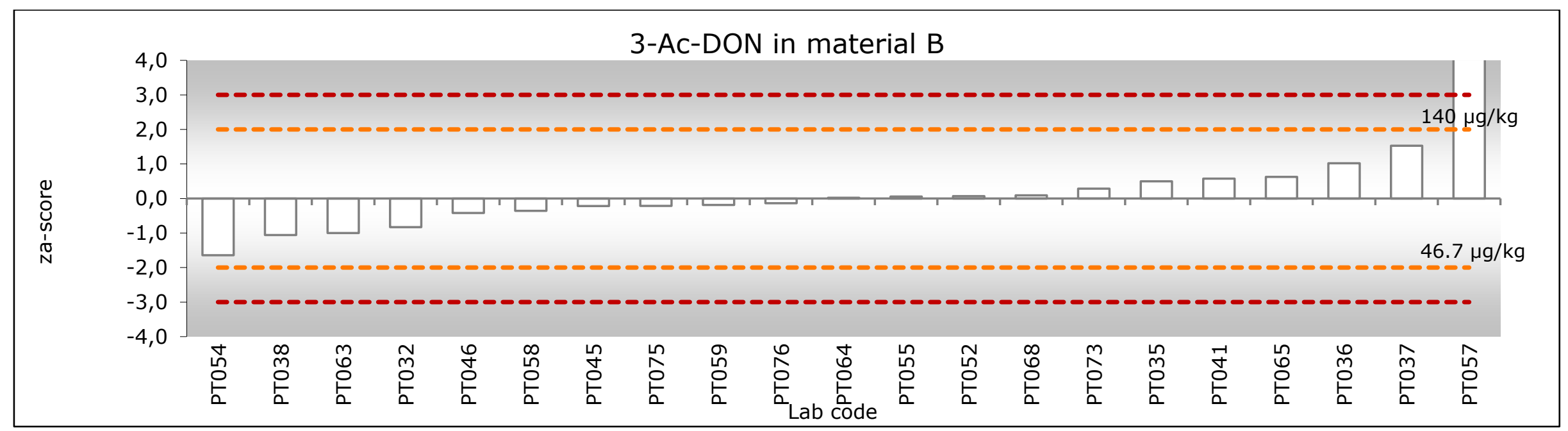

Figure e Graphical representation of the $z$-scores for 3-Ac-DON in material B. Dotted lines show PT performance boundaries \pm 2 (also in $\mu g / k g)$ and \pm 3. 


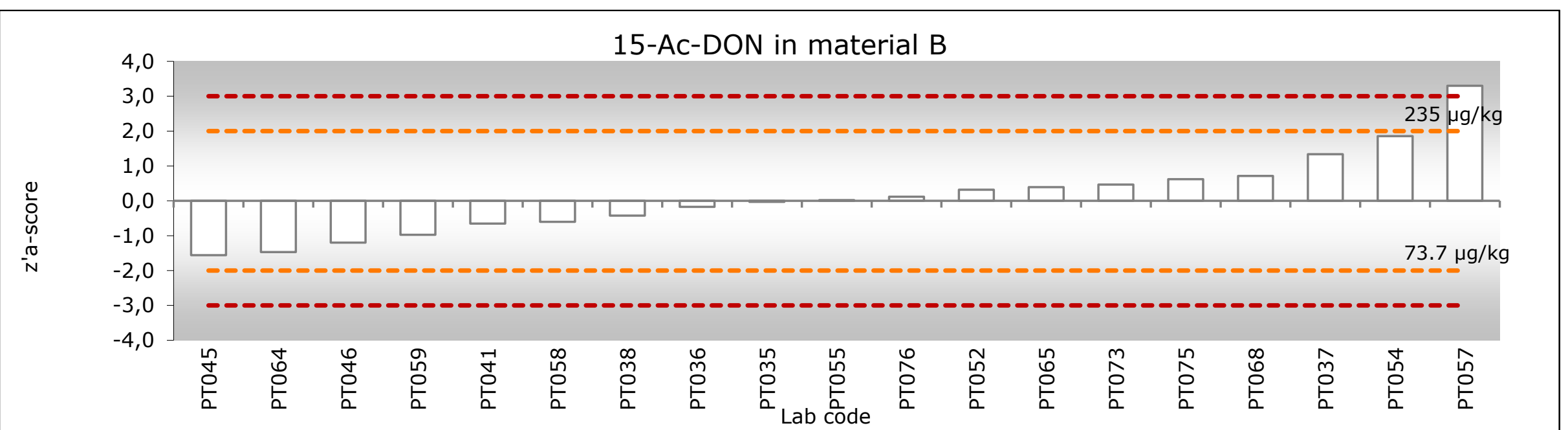

Figure $\boldsymbol{f}$ Graphical representation of the $z^{\prime}-$ scores for $15-A c-D O N$ in material B. Dotted lines show PT performance boundaries \pm 2 (also in $\left.\mu \mathrm{g} / \mathrm{kg}\right)$ and \pm 3 .

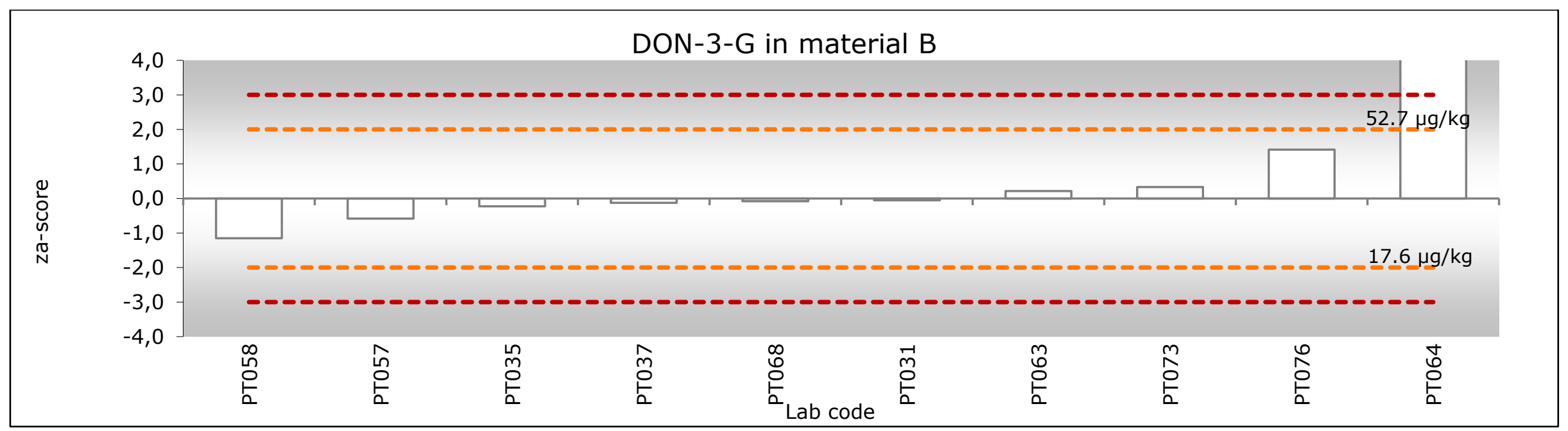

Figure $\mathrm{g}$ Graphical representation of the $z$-scores for DON-3G in material B. Dotted lines show PT performance boundaries \pm 2 (also in $\mu \mathrm{g} / \mathrm{kg})$ and \pm 3 . 


\section{Annex 11 Overview performance per laboratory}

\begin{tabular}{|c|c|c|}
\hline Participant code & $\begin{array}{c}\text { DON } \\
\text { Satisfactory performance* }\end{array}$ & $\begin{array}{c}\text { DON, 3-AC-DON, } 15 \text {-Ac-DON, DON-3C } \\
\text { Satisfactory performance* }\end{array}$ \\
\hline PT031 & 2 out of 2 & 4 out of 7 \\
\hline РT032 & 2 out of 2 & 3 out of 7 [and $1 \mathrm{FP} !]$ \\
\hline РT033 & 0 out of 2 & 0 out of 7 \\
\hline РT034 & 2 out of 2 & 2 out of 7 \\
\hline РT035 & 2 out of 2 & 7 out of 7 \\
\hline РT036 & 2 out of 2 & 4 out of 7 \\
\hline РT037 & 2 out of 2 & 7 out of 7 \\
\hline РT038 & 2 out of 2 & 5 out of 7 \\
\hline РT039 & 2 out of 2 & 2 out of 7 \\
\hline PT040 & 2 out of 2 & 2 out of 7 \\
\hline PT041 & 2 out of 2 & 5 out of 7 [and $1 \mathrm{FP} !]$ \\
\hline РT042 & 2 out of 2 & 2 out of 7 \\
\hline РT043 & 2 out of 2 & 2 out of 7 \\
\hline РT044 & 2 out of 2 & 2 out of 7 \\
\hline РT045 & 2 out of 2 & 4 out of 7 \\
\hline РT046 & 2 out of 2 & 5 out of 7 \\
\hline РT047 & 2 out of 2 & 2 out of 7 \\
\hline РT048 & 2 out of 2 & 2 out of 7 \\
\hline РT049 & 2 out of 2 & 2 out of 7 \\
\hline РT050 & 2 out of 2 & 2 out of 7 \\
\hline РT051 & 2 out of 2 & 2 out of 7 \\
\hline РT052 & 2 out of $2 * *$ & 5 out of $7 * *$ \\
\hline РT053 & 2 out of 2 & 7 out of 7 \\
\hline РT054 & 2 out of 2 & 5 out of 7 \\
\hline PT055 & 2 out of 2 & 6 out of 7 \\
\hline PT056 & 2 out of 2 & 2 out of 7 \\
\hline РT057 & 2 out of 2 & 4 out of 7 \\
\hline PT058 & 2 out of 2 & 7 out of 7 \\
\hline PT059 & 2 out of 2 & 4 out of 7 \\
\hline PT060 & 2 out of 2 & 2 out of 7 \\
\hline PT061 & 2 out of 2 & 3 out of 7 \\
\hline РT062 & 2 out of 2 & 2 out of 7 \\
\hline РT063 & 2 out of 2 & 5 out of 7 [and $1 \mathrm{FPl}]$ \\
\hline РT064 & 2 out of 2 & 5 out of 7 [and 1 FP?] \\
\hline PT065 & 2 out of $2 * *$ & 6 out of $7^{* *}$ \\
\hline РT066 & 2 out of 2 & 2 out of 7 \\
\hline РT067 & 2 out of 2 & 2 out of 7 \\
\hline РT068 & 2 out of 2 & 7 out of 7 \\
\hline РT069 & 2 out of 2 & 2 out of 7 \\
\hline РT070 & 2 out of 2 & 2 out of 7 \\
\hline PT071 & 2 out of 2 & 2 out of 7 \\
\hline РT072 & 2 out of 2 & 2 out of 7 \\
\hline РT073 & 2 out of 2 & 7 out of 7 \\
\hline РT074 & 2 out of 2 & 2 out of 7 \\
\hline PT075 & 2 out of 2 & 5 out of 7 \\
\hline PT076 & 2 out of 2 & 7 out of 7 \\
\hline PT077 & 2 out of 2 & 2 out of 7 \\
\hline PT9958 & 2 out of 2 & 2 out of 7 \\
\hline PT9959 & 2 out of 2 & 2 out of 7 \\
\hline PT9960 & 1 out of 2 & 1 out of 7 \\
\hline
\end{tabular}


RIKILT Wageningen University \& Research P.O. Box 230

6700 AE Wageningen

The Netherlands

$\mathrm{T}+31(0) 317480256$

www.wur.eu/rikilt

RIKILT report 2019.007
The mission of Wageningen University \& Research is "To explore the potential of nature to improve the quality of life". Under the banner Wageningen University \& Research, Wageningen University and the specialised research institutes of the Wageningen Research Foundation have joined forces in contributing to finding solutions to important questions in the domain of healthy food and living environment. With its roughly 30 branches, 5,000 employees and 10,000 students, Wageningen University \& Research is one of the leading organisations in its domain. The unique Wageningen approach lies in its integrated approach to issues and the collaboration between different disciplines. 



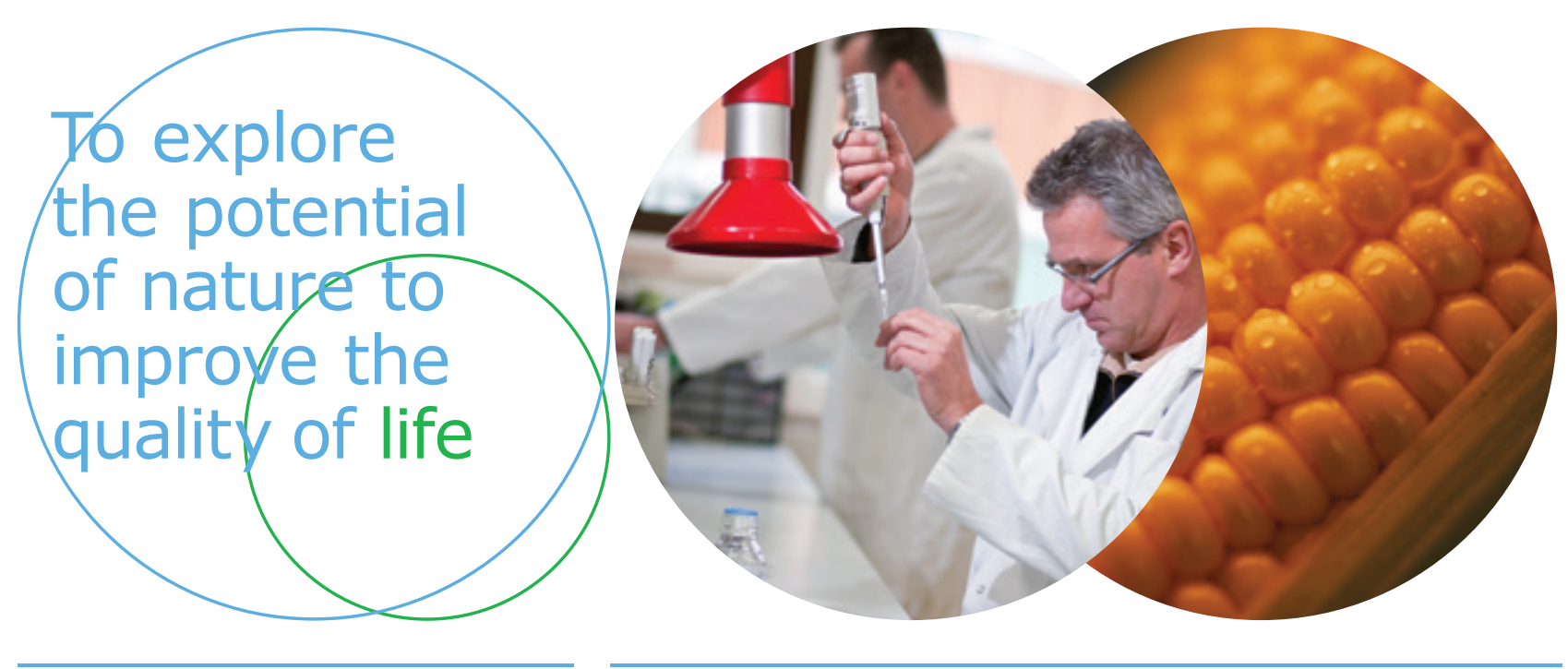

RIKILT Wageningen University \& Research P.O. Box 230

6700 AE Wageningen

The Netherlands

T +31 (0)317480256

www.wur.eu/rikilt

Report 2019.007
The mission of Wageningen University \& Research is "To explore the potential of nature to improve the quality of life". Under the banner Wageningen University $\&$ Research, Wageningen University and the specialised research institutes of the Wageningen Research Foundation have joined forces in contributing to inding solutions to important questions in the domain of healthy food and living environment. With its roughly 30 branches, 5,000 employees and 10,000 students, Wageningen University \& Research is one of the leading organisations in its domain. The unique Wageningen approach lies in its integrated approach to issues and the collaboration between different disciplines. 